\title{
Vulnerability of mesostriatal dopaminergic neurons in Parkinson's disease
}

\section{Tomás González-Hernández 1,2*, Ignacio Cruz-Muros ${ }^{1,2}$, Domingo Afonso-Oramas ${ }^{1}$, Josmar Salas-Hernandez $^{1}$ and Javier Castro-Hernandez ${ }^{1}$}

1 Department of Anatomy, Faculty of Medicine, University of La Laguna, Tenerife, Spain

2 Spanish Network in Neurodegenerative Diseases (CIBERNED), Madrid, Spain

Edited by:

Jose L. Lanciego, University of

Navarra, Spain

Reviewed by:

Thomas Wichman, Emory University,

USA

Jose L. Labandeira-Garcia,

Universidade de Santiago de

Compostela, Spain

*Correspondence:

Tomás González-Hernández, Department of Anatomy, Faculty of Medicine, University of La Laguna, 38207 La Laguna, Tenerife, Spain. e-mail:tgonhern@ull.es
The term vulnerability was first associated with the midbrain dopaminergic neurons 85 years ago, before they were identified as monoaminergic neurons, when Foix and Nicolesco (1925) reported the loss of neuromelanin containing neurons in the midbrain of patients with postencephalitic Parkinson's disease (PD). A few years later, Hassler (1938) showed that degeneration is more intense in the ventral tier of the substantia nigra compacta than in its dorsal tier and the ventral tegmental area (VTA), outlining the concept of differential vulnerability of midbrain dopaminergic (DA-) neurons. Nowadays, we know that other neuronal groups degenerate in $\mathrm{PD}$, but the massive loss of nigral DA-cells is its pathological hallmark, having a pivotal position in the pathophysiology of the disease as it is responsible for the motor symptoms. Data from humans as well as cellular and animal models indicate that DA-cell degeneration is a complex process, probably precipitated by the convergence of different risk factors, mediated by oxidative stress, and involving pathogenic factors arising within the DA-neuron (intrinsic factors), and from its environment and distant interconnected brain regions (extrinsic factors). In light of current data, intrinsic factors seem to be preferentially involved in the first steps of the degenerative process, and extrinsic factors in its progression. A controversial issue is the relative weight of the impairment of common cell functions, such as energy metabolism and proteostasis, and specific dopaminergic functions, such as pacemaking activity and DA handling, in the pathogenesis of DA-cell degeneration. Here we will review the current knowledge about the relevance of these factors at the beginning and during the progression of $\mathrm{PD}$, and in the differential vulnerability of midbrain DA-cells.

Keywords: Parkinson's disease, neurodegeneration, aging, differential vulnerability, nigrostriatal, mesolimbic, mitochondrion, proteostasis

\section{INTRODUCTION}

The level of interest that mesostriatal dopaminergic (DA-) neurons have attained within the brain motor circuits in the last 30 years is mostly because of the relevance of this cell group in the pathophysiology of Parkinson's disease (PD). PD is a neurodegenerative disorder characterized by neuronal loss and the presence of intraneuronal inclusions known as Lewy bodies (LBs) in different brain centers (Braak et al., 2003), which in its sporadic form affects more than $1 \%$ of people over the age of 60 (Nussbaum and Ellis, 2003; de Lau and Breteler, 2006). Besides midbrain DA-cells, this neuronal loss affects the locus coeruleus, dorsal nucleus of the vagus, hypothalamus, nucleus basalis of Meynert, olfactory bulb, and the peripheral and enteric systems, although they do not all display the same susceptibility to degeneration and clinical impact (Pearce et al., 1995; Forno, 1996). Post-mortem studies show that at the end-stage of the disease, the cell loss in non-dopaminergic nuclei ranges between 30 and 50\%, while in the SN it reaches 80\% (Victorof et al., 1996; Zarow et al., 2003; Thannickal et al., 2007), with most DA-cells dying during the preclinical period (Greffard et al., 2006). So, the massive loss of SN DA-cells is considered the hallmark of PD, and responsible for most, if not all, motor symptoms characterizing parkinsonian patients (Hornykiewicz, 2006). Nowadays, basic research is mainly focused on elucidating the cause and cellular mechanisms underlying DA-cell degeneration. Despite these efforts, the etiology and pathogenesis of PD remain unclear. Current data point to it being more of a heterogeneous entity, arising from different causes and pathogenic mechanisms, and converging in a relatively uniform phenotype. A number of studies support the relevance of the impairment of common cellular functions, such as mitochondrial metabolism and protein degradation, and pathogenic mechanisms, such as inflammation and excitotoxicity, while others highlight the role of metabolic and functional aspects specific to DA-cells in the degenerative process. However, the relative weight of each of these factors, and the reason why midbrain DA-cells are particularly susceptible remain unknown. Our knowledge is based on data from different sources, including patients with familial forms of PD, whose clinical and pathological features in many cases differ from those in sporadic $\mathrm{PD}$, and from animal and cellular models based on the manipulation of cellular functions probably involved in the pathogenesis of PD. The aim of this review is to summarize and discuss the current data in favor of and against the relevance of these factors in the sequence of events leading to DA-cell degeneration. 


\section{COMMON CELLULAR FACTORS AND PATHOGENIC MECHANISMS \\ MITOCHONDRIAL DYSFUNCTION}

Mitochondria are organelles where a number of important cellular functions occur, including oxidative energy metabolism, calcium homeostasis, and control of cell death (Kroemer and Blomgren, 2007; Celsi et al., 2009; Galluzzi et al., 2009). Furthermore, deficient mitochondrial metabolism may generate reactive oxygen species with catastrophic consequences for the cell. These facts make mitochondrial dysfunction an attractive candidate for playing a key role in neurodegeneration and aging.

The relationship between mitochondrial dysfunction and DA-cell degeneration was reported for the first time by Schapira et al. (1990) who found reduced activity of mitochondrial complex I (NADH-quinone oxidoereductase) in the substantia nigra of parkinsonian patients. The enzymatic deficiency was later confirmed in the cerebral cortex (Keeney et al., 2006; Parker et al., 2008), and in blood platelets (Krige et al., 1992; Haas et al., 1995; Schapira, 2008), suggesting that a number of patients can undergo a systemic decrease in mitochondrial complex I activity. In addition, cells transfected with mitochondrial DNA from platelets of PD patients show complex I deficiency and other features of PD brains (Swerdlow et al., 1996; Borland et al., 2009).

The involvement of mitochondrial dysfunction was also supported by the finding in the early 80 s of an acute and persistent parkinsonism in humans after intravenous injection of an illicit drug which contained 1-methyl-4-phenyl 1,2,3,6-tetrahydropyridine (MPTP) (Langston et al., 1983). MPTP is converted by the monoamine oxidase enzyme of glial cells into its active metabolite $\mathrm{MPP}^{+}$and taken up by DA-cells through the dopamine transporter (DAT). Once inside the cell, $\mathrm{MPP}^{+}$can exert its neurotoxic effect by means of different mechanisms, including the inhibition of the mitochondrial complex I (Nicklas et al., 1985; Di Monte et al., 1986a; Mizuno et al., 1988). Taking advantage of this effect, MPTP has been widely used for inducing models of PD (DA-cell degeneration) in mice and monkeys (Przedborski and Jackson-Lewis, 1998; Blum et al., 2001).

The structural similarity between $\mathrm{MPP}^{+}$and the herbicide paraquat raised the possibility of a relationship between exposure to environmental toxins, impairment of oxidative phosphorylation and PD. This idea was supported by epidemiological studies reporting a positive association between the incidence of PD and exposure to pesticides (Semchuk et al., 1992; Liou et al., 1997; Dhillon et al., 2008), although others could not confirm such a relationship (Firestone et al., 2005). Experimental data show that paraquat, subchronically administrated in mice, induces midbrain DA-cell loss (McCormack et al., 2002) and $\alpha$-synuclein accumulation (Manning-Bog et al., 2003), but its cytotoxic effect is due to the production of reactive oxygen species at cytosolic level, with potential indirect effects on mitochondria, but not to the direct inhibition of the mitochondrial complex I (Di Monte et al., 1986b; Miller, 2007). Rotenone is another pesticide widely used to induce an animal model of PD (Betarbet et al., 2000; Bove et al., 2005). Its adequacy to reproduce PD features has been a matter of controversy (Cicchetti et al., 2009). Some authors argue a high variability in the lesion pattern, including brain regions unaffected in PD as well as the liver and gastrointestinal tract, suggesting that it acts as a systemic unspecific toxin (Hoglinger et al., 2003; Lapointe et al., 2004). In contrast, others maintain that, by using the appropriate administration schedule, rotenone only produces $\mathrm{PD}$ specific brain lesions, including dopaminergic degeneration, alpha-synucleinpositive inclusions, and impairment of the ubiquitin-proteasome system (UPS) (Sherer et al., 2003; Cannon et al., 2009). Because of its high lipophilicy, rotenone can cross all cell membranes and accumulates in cellular organelles. Its main cytotoxic effect comes from the interaction with the ND1 and PSST subunits of the mitochondrial complex I, resulting in the loss of its enzymatic activity (Schuler and Casida, 2001). Interestingly, although the complex I impairment is evident at the systemic level, degeneration only affects nigrostriatal neurons (Betarbet et al., 2000), supporting the idea that a systemic mitochondrial dysfunction together with the special susceptibility of midbrain DA-cells may be the origin of DA-cell degeneration in sporadic PD.

Convincing evidence for the involvement of mitochondrial dysfunction in the pathogenesis of PD also arises from the discovery of mutations in genes which encode the Parkin, PINK1, DJ-1, $\alpha$-synuclein, and LRRK2 proteins.

Mutations in the Parkin gene (PARK2) were first associated with PD in a Japanese family (Kitada et al., 1998). Today, they are recognized as the most frequent cause of juvenile-onset parkinsonism, although later-onset cases have also been reported (Lohmann et al., 2003). Parkin is a ubiquitously expressed protein, present in different subcellular fractions (Shimura et al., 1999), with several domains for protein-protein interactions and E3 ubiquitin protein ligase activity (Zhang et al., 2000). Parkin-associated endothelinreceptor (Pael-R) is one of the substrates of parkin ligase activity which has been shown to be accumulated in the brain of patients with PARK2 mutations. When this receptor is overexpressed in cells it tends to become unfolded and insoluble, and induces cell death (Imai et al., 2001). Parkin has also been recognized as a mitochondrial protection factor. Its overexpression in cells prevents the mitochondrial swelling induced by ceramide (Darios et al., 2003), upregulates the expression of complex I subunits and reduces the accumulation of reactive oxygen species in mitochondria (Kuroda et al., 2006). While its deficiency leads to a decrease in the levels of complex I and IV subunits and mitochondrial respiratory capacity in mice (Palacino et al., 2004).

PTEN-induced putative kinase 1 (PINK1) is a serine/threonine kinase with autophosphorylation capacity which is transcribed in the nucleus, and imported to the mitochondria (Silvestri et al., 2005). Its mutations are associated with hereditary early-onset PD, although heterozygous mutations have also been found in sporadic early-onset forms (Valente et al., 2004). PINK1 regulates the activity and phosphorylation of TRAP1 (TNF-receptor-associated protein 1), a protein which acts as a chaperone to prevent protein misfolding (Pridgeon et al., 2007), HtrA2/Omi, which acts as a protease involved in the degradation of misfolded proteins (Alnemri, 2007), and Parkin. PINK1 regulates the mitochondrial localization of Parkin through its phosphorylation (Kim et al., 2008). Neurons from PINK1 knockout mice develop mitochondrial dysfunction, including reduced membrane potential, increased production of oxygen radicals and sensitivity to apoptosis (Wood-Kaczmar et al., 2008). Furthermore, the striatum of PINK1 knockout mice shows an increase in the number of large mitochondria and impairment 
of complex I and II activity (Gautier et al., 2008). So, mitochondrial dysfunction induced by PINK1 mutations may in part be due to defects in Parkin functions.

DJ-1 is a 189 amino acid/20 kDa multifunctional protein with antioxidant and transcription modulatory activity (Takahashi et al., 2001; Taira et al., 2004). Under normal conditions, DJ-1 preferentially localizes in the cytosol, but under conditions of oxidative stress it translocates to the mitochondria and nucleus (Zhang et al., 2005). This redistribution ability has been related to its neuroprotective capacity (Canet-Aviles et al., 2004; Ashley et al., 2009). Mutations in its encoding gene (PARK7) are a rare cause of recessively inherited PD (Bonifati et al., 2003). DJ-1 deficient mice show motor abnormalities and changes in DA handing, but not spontaneous DA-cell degeneration (Goldberg et al., 2005). However, they become more susceptible to MPTP than their wild-type congeners (Kim et al., 2005).

Alpha-synuclein is a presynaptic protein whose relevance in $\mathrm{PD}$ comes from the fact that it is present in LBs, and because mutations and triplications of its gene locus (PARK1) are a cause of autosomal dominant PD (Polymeropoulos et al., 1997; Singleton et al., 2003). The mechanism by which $\alpha$-synuclein exerts its toxicity has been related to the tendency of the mutated and overexpressed protein to aggregate in form of fibrils (Conway et al., 2000; Fredenburg et al., 2007). Oligomeric intermediates of the $\alpha$-synuclein fibrillation pathway, called protofibrils, can form annular pores in cell membranes, including those of mitochondria, leading to their permeabilization. This phenomenon may be enhanced in DA-cells because cytosolic DA interacts with $\alpha$-synuclein slowing the conversion of protofibrils to fibrils (Conway et al., 2000; Rochet et al., 2004). Overexpression of mutant and wild-type $\alpha$-synuclein can induce damage at different cell levels, including proteasome, endoplasmic reticulum, and mitochondria (Hsu et al., 2000). Mitochondrial impairment includes oxidation of mitochondriaassociated proteins (Poon et al., 2005), mitochondrial DNA damage and reduced complex IV activity (Martin et al., 2006). In this respect, higher $\alpha$-synuclein levels have been found in mitochondria from substantia nigra of PD patients than in those from healthy individuals (Devi et al., 2008).

Leucine-rich repeat kinase 2 (LRRK2) is a widely distributed protein with a multidomain structure which includes a serine/ threonine kinase domain (Giasson et al., 2006). Mutations in the gene encoding LRRK2 (PARK8) are a common cause of autosomal dominant $\mathrm{PD}$, and are also present in about $1 \%$ of patients with sporadic PD (Paisan-Ruiz et al., 2004; Di Fonzo et al., 2005). The toxicity of several of these mutations appears to be associated with an increase in its kinase activity (Gloeckner et al., 2006). Although the involvement of mitochondria in the pathogenesis of LRRK2 mutant-associated PD remains unclear, the facts that LRRK2 partially colocalizes with mitochondrial markers (Biskup et al., 2006), and that overexpression of mutant LRRK2 proteins induces Apaf1 dependent apoptosis (Iaccarino et al., 2007), suggest that LRRK2 mutations can compromise mitochondrial function.

In sum, a large body of evidence supports the idea that mitochondrial dysfunction plays a key role in the pathogenesis of DA-cell degeneration. However, this idea is challenged by certain facts. For example, diseases associated with mitochondrial DNA mutations are typically multisystemic, involving heart, skeletal muscle, and brain, but not specifically DA-cells. Furthermore, DA-cell degeneration is not relevant in most neurodegenerative diseases associated with mutations in the nuclear genes which encode proteins that are targeted to mitochondria (Schon and Manfredi, 2003). Thus, although mitochondria impairment may be involved in the degenerative process in many cases of $\mathrm{PD}$, other factors must contribute to making DA-cells particularly vulnerable in this disorder.

\section{PROTEIN HOMEOSTASIS}

Cells control the quantity and quality of intracellular proteins through the balance between the rate of their synthesis, maturation and degradation (Shah and Di Napoli, 2007). Folding is part of this process converting newly synthesized proteins into functional molecules. The endoplasmic reticulum contains most of the machinery responsible for maintaining an appropriate protein folding through a coordinated signaling program known as unfolded protein response (UPR) (Hosoi and Ozawa, 2009). The response of the endoplasmic reticulum includes translational attenuation, induction of chaperones, and degradation of misfolded proteins. The two principal pathways of intracellular protein degradation are the UPS, responsible for the bulk of the turnover of short-lived cytosolic proteins, and the autophagylysosome pathway (ALP), involved in the degradation of longlived stable proteins as well as in the recycling of organelles (Jellinger, 2009). The capacity of this proteostasis network is enough to maintain protein homeostasis under normal conditions and under short-term stressful circumstances. However, this seems to be overwhelmed by chronic stress as probably occurs in aging, cancer, or metabolic and neurodegenerative diseases. In these cases, proteins lose their normal configuration and activity, and become misfolded with a propensity to aggregate. The structural instability of some mutated or postranslationally modified proteins makes them particularly inclined to aggregate to each other as well as to other normal proteins. These protein aggregates may interfere with critical intracellular processes including UPR function, and induce cytotoxicity.

A number of findings indicate that these cellular functions are compromised in DA-cells in PD. For example, proteinaceous aggregations, containing ubiquitin, and $\alpha$-synuclein and known as Lewy bodies (LBs), are abundant in the $\mathrm{SN}$ and other brain centers affected by degeneration in sporadic PD (Braak et al., 2003). The enzymatic activity and expression of some $\alpha$-subunits of the proteasome and the proteasomal activator PA700 have been found to be low in the SN of PD patients, while in unaffected brain regions they are high, suggesting that neurons in these regions, but not those in the $\mathrm{SN}$, can activate compensatory responses against the proteolytic stress (McNaught et al., 2001, 2003). Even in healthy subjects, the levels of the proteasome activator PA28 in the SN pars compacta $(\mathrm{SNc}$ ) have been reported to be lower than in other brain regions (McNaught et al., 2002a, 2003). In addition, a recent immunohistochemistry study showed that under normal conditions, PA28 and PA700 expression are very low in the rat SNc, and that different stressful stimuli induce PA28/PA700 overexpression in a variety of cells but not in midbrain DA-neurons (McNaught et al., 2010). Therefore, it is possible that the UPS is constitutively weak in midbrain DA-cells, contributing to their particular vulnerability in sporadic PD. 
The relevance of proteolytic stress is also supported by data arising from familial PD. As mentioned above, although the mechanism by which Parkin mutations induce degeneration is not well known, it has been mainly related to a defect in its ubiquitin ligase activity. Parkin interacts with the $26 \mathrm{~S}$ proteosome through its ubiquitin ligase domain facilitating the recognition of ubiquitinated substrates by the proteasomal activator PA700 (Pickart, 2004). Parkin acts in conjunction with other enzymes to ubiquitinate a variety of substrates, such as Pael-R, which have been found to be accumulated and non-ubiquinated in LBs (Murakami et al., 2004). In addition, Parkin prevents cell death induced by overexpression of Pael-R (Imai et al., 2001). Therefore, Parkin mutations could impair ubiquitination and degradation of substrate proteins which might be aggregated and cause cytotoxicity.

Ubiquitin C-terminal hydrolase L1 (UCH-L1) is a 230 amino acid/26 $\mathrm{kDa}$ protein only expressed in neurons, which acts as a deubiquinating enzyme removing ubiquitin from protein adducts before their entry in the proteosome (Leroy et al., 1998). A missense mutation in the UCH-L1 gene (PARK5) has been found in two German siblings with $\mathrm{PD}$, and is considered today to be a rare cause of familiar PD (Olanow and McNaught, 2006). It has been reported that the in vitro deubiquinating activity of mutated UCH-L1 form is low (Nishikawa et al., 2003), and that inhibition of the ubiquitin hydrolase activity leads to the formation of LB-like inclusions and DA-cell degeneration in cell cultures (McNaught et al., 2002b). So, it is possible that, in these patients, deubiquitination failure blocks the proteasomal processing of proteins, leads to the formation of aggregates and interferes with the supply of ubiquitin monomers to additional unwanted proteins (Olanow and McNaught, 2006).

The protective role of DJ-1 has been mostly associated to its ability to translocate to the mitochondria and nucleus where it can exert antioxidant and transcriptional modulatory actions (Zhang et al., 2005). However, its molecular structure and in vitro properties indicate that it can also work as a molecular chaperone and protease (Abou-Sleiman et al., 2003; Lee et al., 2003). In addition, such proteolytic activity is lost when it is mutated (Olzmann et al., 2004; Shendelman et al., 2004). So, mutations in DJ-1 can compromise UPS function and promote protein aggregation.

Under physiological conditions, $\alpha$-synuclein is monomeric and unfolded, and preferentially degraded by the proteasome in an ubiquitin-independent manner (Bennett et al., 1999). But in high concentration or as a mutated form, it resists proteasomal degradation (Stefanis et al., 2001; Tanaka et al., 2001), becomes misfolded and oligomeric, and tends to self-aggregate and aggregate to other proteins (Bennett, 2005). As mentioned above, the toxicity of $\alpha$-synuclein has been related to the ability of $\alpha$-synuclein intermediate aggregates to form ring-like pores in cellular membranes, increasing their permeability (Lashuel et al., 2002). In vitro studies reveal that $\alpha$-synuclein aggregates can also bind to the proteasomal protein S6', a subunit of the 19 S cap of the 26 S proteasome, resulting in the inhibition of its function (Snyder et al., 2003).

On the other hand, similar to other protein complexes and membrane proteins too large in size to pass through the proteasome barrel, $\alpha$-synuclein oligomers and aggregates can also be cleared by the ALP (Pan et al., 2008). The principal pathways for $\alpha$-synuclein clearance through lysosomes are the macroautophagy, which is also involved in the recycling of damaged organelles, and the chaperone-mediated autophagy (CMA) (Cuervo et al., 2004). In CMA, $\alpha$-synuclein couples to the chaperone $\mathrm{Hsc} 70$ forming a protein-molecular chaperone complex that binds to the lysosomal membrane (Mak et al., 2010). The A30P and A53T $\alpha$-synuclein mutants, which are associated with familial PD, remain firmly attached to the chaperone, blocking their lysosomal translocation and degradation, and the binding of other CMA protein substrates (Cuervo et al., 2004; Pan et al., 2008). In addition, missense mutations of the gene encoding lysosomal ATPase 13A2 (PARK9), which are associated with an atypical form of juvenile-onset PD, lead to deficient autophagy activity with $\alpha$-synuclein aggregation (Ramirez et al., 2006).

In spite of the unequivocal evidence for the impairment of proteostasis in the pathogenesis of DA-cell degeneration, it is still not clear whether degeneration starts with this phenomenon, whether the proteolytic stress does or does not play a determinant role in the relative specificity of DA-cell loss in PD, and whether LB-like proteinaceous inclusions are toxic entities promoting neuron death or whether they represent protective mechanisms by which neurons sequester unwanted proteins (Harrower et al., 2005). Based on the regional distribution of LBs, Braak et al. (2003) proposed a neuropathological staging scheme according to which PD starts in non-dopaminergic structures of the medulla oblongata and progresses rostrally, affecting nigral DA-cells later on in the course of the disease. However, this idea contrasts with quantitative studies reporting that most $\mathrm{SN}$ cell loss and striatal denervation occurs during the 5-10 year preclinical period (Gibb and Lees, 1988; Greffard et al., 2006), suggesting that cell loss and $\alpha$-synuclein deposition are not parallel processes (Burke et al., 2008). It should also be noted that LBs and $\alpha$-synuclein immunoreactive inclusions are present in different brain regions in different neurodegenerative diseases encompassed by the term LB disorders, including PD with dementia and dementia with LBs (Lippa et al., 2007), and in normal aging (Hindle, 2010); that the density of LBs in neurodegenerative diseases does not correlate with the intensity of cell degeneration, and that LBs are virtually absent in juvenile-onset PD associated with Parkin mutations (Olanow and McNaught, 2006).

\section{NEUROINFLAMMATION}

The participation of inflammatory reaction in the degeneration of midbrain DA-cells was suggested for the first time by the report of an increased number of microglial cells immunoreactive for the major histocompatibility complex (MHC) antigen II in the SN of PD patients (McGeer et al., 1988). The presence of activated microglia was thereafter confirmed using other markers of microglial activation (Mogi et al., 1994a; Banati et al., 1998; Imamura et al., 2003). The fact that DA-cells express the receptors for some of the cytokines found in the $\mathrm{SN}$ of $\mathrm{PD}$ patients, such as the tumor necrosis factor (TNF) $\alpha$, interleukin (IL)- $1 \beta$ and interferon $\gamma$ (Boka et al., 1994), and that the expression of some of these, e.g., TNF $\alpha$ receptor 1, increases in PD (Mogi et al., 2000), indicates that DA-cells may be sensitive to the direct effect of cytokines. However, cytokines can also affect DA-cells by inducing enzymes such as nitric oxide synthase, cyclo-oxygenase 2, and NADPH-oxidase which produce toxic reactive species (Hunot et al., 1996; Knott et al., 2000).

Interestingly, an analysis of cerebrospinal fluid in $\mathrm{PD}$ patients showed an increase in TNF $\alpha$, IL-1 $\beta$, and IL-6 concentration (Mogi et al., 1994b; Blum-Degen et al., 1995), and an analysis of 
peripheral blood showed an increase in activated CD4(+) CD25(+) lymphocytes (Bas et al., 2001). Furthermore, the population of circulating CD3+ CD4 bright+ CD8 dull+ lymphocytes is significantly greater in $\mathrm{PD}$ patients than in age-matched control subjects (Hisanaga et al., 2001). Since the count of these lymphocytes usually increases after a viral infection, the authors proposed that postinfectious immune abnormalities could be associated with the pathogenesis of PD.

Animal and cellular models of PD have reproduced most cellular and molecular inflammatory events observed in the brain of PD patients, but have also provided additional insight for understanding the role of inflammation in DA-cell degeneration. For example, microglial activation has been found in the SN of mice and monkeys after peripheral injection of MPTP (Liberatore et al., 1999; Hurley et al., 2003; McGeer et al., 2003). The addition of $\alpha$-synuclein or neuromelanin, two products released by degenerating DA-cells, to microglial cultures induces activation of proinflammatory pathways, and the injection of $\alpha$-synuclein protofibrils in the rat SN induces microglial activation and loss of adjacent neurons (Wilms et al., 2003, 2009). Furthermore, the administration of steroidal and non-steroidal anti-inflammatory drugs reduce the toxicity of 6-OHDA and MPTP in rodents (Kurkowska-Jastrzebska et al., 2002; Di Matteo et al., 2006; Hirsch and Hunot, 2009). Taken together, these findings suggest that damaged DA-cells might upregulate and/or release products which activate microglial cells, and these lead to a local neuroinflammatory reaction which helps to perpetuate degeneration. Interestingly, recent in vivo and in vitro studies show that DA-degeneration induces an increase in the activity of angiotensin converting enzyme and angiotensin II (AII) levels, that the addition of AII to midbrain cell cultures increases 6-OHDA toxicity, and that angiotensin type-1 receptor antagonists inhibit both DA-cell degeneration and NADPH-oxidase and early microglial activation (Muñoz et al., 2006; Rodriguez-Pallares et al., 2008; Joglar et al., 2009). So, the brain angiotensin system may play a key role in the inflammatory process in PD. The fact that inflammatory changes are also present in other neurodegenerative disorders, such as Alzheimer's disease, Huntington's disease and amyotrophic lateral sclerosis (McGeer and McGeer, 2004), suggests a common phenomenon in the progression of neuronal degeneration.

\section{GLUTAMATE EXCITOTOXICITY}

Glutamate is the major excitatory neurotransmitter in the mammalian brain, and is also a potent neurotoxin when it reaches high extracellular concentrations. The levels of extracellular glutamate are regulated by neuronal and glial transporters, and by its metabolism and recycling via glutamine synthetase in astrocytes, which prevent the extracellular glutamate concentration from rising to neurotoxic values (Plaitakis and Shashidharan, 2000; Dervan et al., 2004). Glutamatergic actions are exerted through two families of glutamate receptors, ionotropic and metabotropic. According to their agonist selectivity, ionotropic receptors have been classified into: $N$-methyl-D-aspartate (NMDA), $\alpha$-amino-3-hydroxyl-5methyl-4-isoxazole-propionate (AMPA), and kainic acid (KA) receptors (Burnashev et al., 1992; Hollmann and Heinemann, 1994; Geiger et al., 1995). Metabotropic receptors are coupled by G-proteins to different secondary messenger systems, and have also been classified into different groups (Groups I-III; Conn and Pin,
1997). Extracellular glutamate comes from two different sources, the neuronal $\mathrm{Ca}^{2+}$-dependent pool, and the glial $\mathrm{Ca}^{2+}$-independent pool. Under basal conditions, the glial pool provides $60 \%$ of extracellular glutamate, although at present its functional relevance is controversial. After $\mathrm{K}^{+}$-induced depolarization, the neuronal pool augments from $30 \%$ to $60 \%$ of the total extracellular glutamate (Xue et al., 1996; Baker et al., 2002; Cavelier and Attwell, 2005). Current data show that the glutamatergic input to the $\mathrm{SN}$ comes from the pedunculopontine tegmental nucleus (PPN), and particularly from the subthalamic nucleus (STN) (Charara et al., 1996; Iribe et al., 1999; Forster and Blaha, 2003). Curiously, hodological and electron microscopic studies indicate that the bulk of subthalamic afferents to the $\mathrm{SN}$ reach the pars reticulata and form asymmetrical synapses with TH-negative (presumably GABAergic) dendrites, with those making contact with $\mathrm{TH}$-positive being more than 10\% (Kita and Kitai, 1987). So, depending on the target cell and the receptor type, glutamate can directly excite DA-cells, indirectly inhibit them by exciting GABAergic neurons, and directly inhibit or excite them by activating metabotropic receptors on DA-cells (Lee and Tepper, 2009).

Glutamate signaling may be affected by alterations in its homeostasis, which leads to an increase in the extracellular concentration, or by alterations in the energy metabolism of its target cells, which lead to a decrease in the activation threshold for their receptors, particularly those of the NMDA type (Novelli et al., 1988). Experimental data indicate that glutamate might contribute to DA-cell degeneration by means of both mechanisms. In a model of PD in mice, the loss of striatal DA-terminals is accompanied by an increase in the size and number of astrocytes, but the density of transporters per astrocyte is low, suggesting that the astrocyte function is compromised (Dervan et al., 2004). On the other hand, NMDA antagonists reduce the loss of DA-neurons due to the inhibition of the cellular metabolism in midbrain cell culture (Zeevalk et al., 1998), and the loss of DA-cells induced by $\mathrm{MPP}^{+}$and MPTP in rodents and in non-human primates (Turski and Lachowicz, 1991). STN activity has been found to be enhanced in both the experimental models of PD (Bergman et al., 1994) and in the PD patients (Benazzouz et al., 2002), and its modulation results in an improvement of motor symptoms (Limousin et al., 1998; Garcia et al., 2005). Hyperactivity of STN has even been detected before the appearance of clinical signs in MPTP-treated monkeys, suggesting that it may be a compensatory mechanism for the maintenance of striatal dopaminergic homeostasis (Bezard et al., 1999a), but it could also contribute to the progression of DA-cell loss from the first stages of the disease.

\section{AGING}

The relationship between aging and DA-cell degeneration is based on several facts. PD in its sporadic form is an age-related degenerative disorder, with a mean onset age of 55 , and the incidence increases from 20/100.000 to 120/100.000 at age 70 (Dauer and Przedborski, 2003). Lewy bodies, the pathological hallmarks of PD (Braak et al., 2003), are also present in normal aged brains (Saito et al., 2004; Hindle, 2010). Oxidative stress is currently considered to play a central role in both aging (Harman, 1956; Squier, 2001) and PD (Dauer and Przedborski, 2003; Jenner, 2003). Mitochondrial DNA deletions occurring during normal aging, probably as a consequence 
of oxidative stress, are particularly abundant in midbrain DA-cells (Bender et al., 2006; Kraytsberg et al., 2006). In addition, morphological studies in monkeys (Pakkenberg et al., 1995; Gerhardt et al., 2002) and humans (McGeer et al., 1977; Fearnley and Lees, 1991; Pakkenberg et al., 1995; Cabello et al., 2002; Gerhardt et al., 2002) have reported a decrease in the number of midbrain DA-cells with age, suggesting that midbrain DA-neurons undergo a low intensity degenerative process during normal aging. Based on these findings, it has been proposed that everyone should get PD if they live long enough (Chan et al., 2007; Surmeier, 2007). However, this idea is challenged by other studies performed on monkeys (Irwin et al., 1994; McCormack et al., 2004; Collier et al., 2007) and humans (Kubis et al., 2000) according to which the number of midbrain DA-cells does not change during normal aging, suggesting that the age-related loss of striatal DA levels (Kish et al., 1992; Haycock et al., 2003 ) is due to a progressive chemical and functional decline rather than to degeneration. Furthermore, biochemical studies performed on humans show that the regional pattern of striatal DA loss during normal aging substantially differs from that typically observed in PD (Kish et al., 1992). Consistent with these data, we have recently observed that the loss of DA in aged rats is higher in the ventral striatum than in the dorsal striatum (Cruz-Muros et al., 2007). In addition, two different age-related processes were detected. One is characterized by DOPA decarboxylase decrease involving both the nigrostriatal and the mesolimbic compartments, and is responsible for the moderate DA decrease in the dorsal striatum. The other process is characterized by axonal degeneration and aggregation of $\alpha$-synuclein in their original somata, restricted to mesolimbic regions and responsible for the decline of tyrosine hydroxylase activity and the greater decrease in DA levels in this compartment. Therefore, although both the nigrostriatal and the mesolimbic systems are vulnerable to aging, in contrast to what occurs in PD, the mesolimbic system seems to be more vulnerable to normal aging than the nigrostriatal system. Furthermore, although several age-related aspects, such as oxidative stress or impairment of the energy metabolism, make aging the most important risk factor for PD, anatomical and biochemical features of normal aging in the mesostriatal system seem to be more probably related to ageassociated behavioral and mood disturbances than to parkinsonian motor signs.

\section{SPECIFIC DOPAMINERGIC FACTORS}

The aforementioned studies indicate that intrinsic (mitochondrial dysfunction and proteostasis impairment), extrinsic (neuroinflammation and excitotoxicity) and age-related factors participate in the degenerative process of DA-cells in PD. However, a question of critical importance remains to be solved: why are midbrain DA-neurons, and especially some of these neurons, particularly vulnerable to degeneration? It is known that in $\mathrm{PD}, \mathrm{DA}$-cells in the $\mathrm{SN}$ are more vulnerable than those in the VTA, and that within the $\mathrm{SN}$, neurons lying in its ventrolateral and caudal region $(\mathrm{SNcv})$ are more vulnerable than those in the rostromedial and dorsal region (SNrm) (Hassler, 1938; German et al., 1989; Damier et al., 1999). However, there is no evidence for substantial differences in the ER, mitochondria or other structural organelles between DA-cells and non-DA cells, or between midbrain DA-cells that show different susceptibility to degeneration. So, differential vulnerability should be linked to physiological, neurochemical, and/or metabolic aspects which are specific to DA-cells and also differ from one DA-subpopulation to another, making some of them more vulnerable or resistant.

\section{PHYSIOLOGICAL PROFILE OF DA-NEURONS}

A characteristic of midbrain DA-cells is that, unlike most neurons in the brain, they display two electrophysiological patterns. One phasic pattern in the form of bursts of action potentials with a mean frequency of $20 \mathrm{~Hz}$ and triggered by excitatory inputs from different sources (Schultz, 2002; Omelchenko and Sesack, 2005), and the other tonic pattern, with a mean frequency of $2-4 \mathrm{~Hz}$ and which is generated in absence of afferents (Sulzer and Schmitz, 2007). This intrinsic pacemaking activity is believed to be important in maintaining basal DA levels in the striatum, and may be detected from the first postnatal days in mice. During the first weeks, this is driven by sodium and hyperpolarization-activated and cyclic nucleotide-gated cation $\left(\mathrm{Na}^{+} / \mathrm{HCN}\right)$ channels. Thereafter, the expression of L-type $\mathrm{Ca}^{2+}$ channels increases in SN DA-cells, and the pacemaking is driven by $\mathrm{Ca}^{2+}$ currents. Adult VTA DA-cells also have L-type $\mathrm{Ca}^{2+}$ channels, but as opposed to SN DA-cells, their pacemaking continues to be driven by sodium channels. The L-type $\mathrm{Ca}^{2+}$ channels used by SN DA-cells have a $\mathrm{Ca}_{\mathrm{v}} 1.3$ pore-forming subunit which allows them to open at a relatively hyperpolarized potential (Striessnig et al., 2006; Chan et al., 2007). While in most cells, $\mathrm{Ca}^{2+}$ channel opening is a rare and brief event, the sustained used of $\mathrm{Ca}_{\mathrm{v}} 1.3 \mathrm{Ca}^{2+}$ channels by SN DA-cells results in a large $\mathrm{Ca}^{2+}$ influx which requires a high metabolic cost to be handled. Cytosolic $\mathrm{Ca}^{2+}$ should be pumped back across the plasma membrane against a concentration gradient or rapidly sequestered. The two organelles most directly involved in $\mathrm{Ca}^{2+}$ handling are ER and mitochondrion. Cytosolic $\mathrm{Ca}^{2+}$ is moved into ER by high-affinity ATP-dependent transporters. Thereafter, it is released to the cytosol to be used in modulatory functions or pumped to the extracellular space (Berridge, 2002; Choi et al., 2006). $\mathrm{Ca}^{2+}$ released from the ER can also enter mitochondria through apposition points between both organelles (Rizzuto and Pozzan, 2006). This ER-mitochondrial system contributes to $\mathrm{Ca}^{2+}$ buffering but also to ATP production (McCormack et al., 1990). However, it may be overburdened by the sustained use of $\mathrm{Ca}_{\mathrm{v}} 1.3 \mathrm{Ca}^{2+}$ channels. Both depletion and increase in intraluminal $\mathrm{ER} \mathrm{Ca}^{2+}$ concentration induce ER stress and compromise proteostasis (LaFerla, 2002; Paschen and Mengesdorf, 2005). Furthermore, the high demand of ATP needed to move $\mathrm{Ca}^{2}$ out of the cell increases the electron transport chain activity leading to the production of reactive oxygen species (Sulzer and Schmitz, 2007; Chan et al., 2009). The relevance of the $\mathrm{Ca}^{2+}$-dependence of pacemaking activity in the vulnerability of SN DA-cells is based on the finding that blockade of $\mathrm{Ca}_{\mathrm{v}} 1.3 \mathrm{Ca}^{2+}$ channels in adult $\mathrm{SN}$ DA-cells induces a reversion of the pacemaking pattern to that of adult VTA and juvenile SN DA-cells, also protecting them against rotenone and MPTP (Chan et al., 2007). Reinforcing the role $\mathrm{Ca}^{2+}$ homeostasis in the differential vulnerability of midbrain DA-cells, DA-cells in the dorsomedial region of SN and VTA express calbindin- $\mathrm{D}_{28 \mathrm{k}}$ (Gerfen et al., 1987; McRitchie and Halliday, 1995; Liang et al., 1996; McRitchie et al., 1996). The ability of this protein to buffer intracellular $\mathrm{Ca}^{2+}$, together with its localization in DA-cell subpopulations resistant to degeneration, have suggested 
that calbindin- $\mathrm{D}_{28 \mathrm{k}}$ confers neuroprotection (Gerfen et al., 1985; Yamada et al., 1990; German et al., 1992). However, some findings contrast with this hypothesis. For example, no differences have been observed between the neurotoxic effect of MPTP in midbrain-DA cells of calbindin- $\mathrm{D}_{28 \mathrm{k}}$-deficient mice and their wild-type littermates (Airaksinen et al., 1997). Furthermore, DA-cells in the lateral region of the $\mathrm{SN}$ which express calbindin- $\mathrm{D}_{28 \mathrm{k}}$ are more sensitive to the neurotoxic effect of 6-OHDA than other SN DA-cells which do not express calbindin- $\mathrm{D}_{28 \mathrm{k}}$ (Rodriguez et al., 2001).

\section{METABOLIC PHENOTYPE OF DA-NEURONS}

Another peculiarity of DA-cells implicated in their vulnerability concerns DA itself. Under normal conditions, most DA acting as a neurotransmitter is contained inside synaptic vesicles of DA-cells (Jonsson, 1971). When DA concentration increases in the cytosol, DA is rapidly metabolized via monoamino oxidase or by autooxidation. Both enzymatic and non-enzymatic catabolisms of DA are important sources of reactive oxygen species which have been implicated in DA-cell degeneration. Through its enzymatic metabolism, DA is converted into 3,4-dihydroxyphenylacetaldehyde and 3,4-dihydroxyphenylacetic acid, also generating hydrogen peroxide. This may be neutralized by antioxidant enzymes, or, in the presence of iron, generate high toxic hydroxyl radicals. Through autooxidation, DA is converted into reactive quinones and superoxide anion. This can be converted into hydrogen peroxide by superoxide dismutase, or react with nitric oxide to generate the highly toxic radical peroxynitrite (Barzilai et al., 2001). Reactive quinones may be oxidized to cyclized aminochromes, which are thereafter polymerized to form neuromelanin, or interact with cysteine residues of different molecules inhibiting their activity (Miyazaki and Asanuma, 2009). On the basis of this interaction, the formation of quinones by DA oxidation has gained interest in the pathogenesis of PD. There are studies supporting the notion that DA-quinone, or some of its metabolic products, can inhibit the ubiquitin ligase activity of parkin (LaVoie et al., 2005), the permeability of mitochondrial pores (Berman and Hasting, 1999) and the proteasomal function (Zafar et al., 2006), as well as induce microglial activation (Kuhn et al., 2006).

Neuromelanin is another product from the DA metabolism that has been implicated in the pathogenesis of PD. Neuromelanin is a complex polymeric molecule which probably arises from both the enzymatic (Hasting, 1995; Sanchez-Ferrer et al., 1995) and nonenzymatic (Fornsted et al., 1986; Sulzer et al., 2000) metabolism of catecholamines, and is particularly abundant in DA-cells in the SN and noradrenergic cells in the locus coeruleus of humans, being responsible of their dark color (Fasano et al., 2006). Neuromelanin was first proposed as playing a role in PD on the basis of morphological studies reporting a correlation between neuromelanin concentration and DA-cell degeneration (Mann and Yates, 1983; Hirsch et al., 1988). However, this idea was challenged by the report that DA-cells in the dorsal tier of the SN contain higher levels of neuromelanin than those in the ventral tier which are more vulnerable to degeneration (Gibb, 1992). Experimental studies performed during the last two decades indicate that neuromelanin may play a dual role, protecting from or contributing to DA-cell degeneration, depending on the environment (Ben-Shachar et al., 1991; Sulzer et al., 2000). On the one hand, neuromelanin can bind
MPP+ (D’Amato et al., 1986) and paraquat (Lindquist et al., 1988), reducing their neurotoxicity, and accumulate dopaminergic drugs, regulating their intracellular concentration (Salazar et al., 1978). Neuromelanin also has the capability to sequester redox-active ions, including iron, thereby reducing the formation of free hydroxyl radicals (Enochs et al., 1994; Zecca et al., 2003). However, under oxidative conditions, neuromelanin can interact with hydrogen peroxide, becoming a source of free radicals and releasing toxic metals which accelerate cell death (Swartz et al., 1992; Shima et al., 1997). In addition, as mentioned above (Wilms et al., 2003), neuromelanin released from degenerated DA-cells can induce microglial activation, also perpetuating the degenerative process.

It should be also noted that the cytosolic levels of DA are closely related to two transport processes: DA uptake from the extracellular space, and once inside the cell, DA packing into small synaptic vesicles. DA uptake is performed by the DAT, a 12-transmembrane domain glycoprotein with three $\mathrm{N}$-glycosylation sites in the second extracellular loop (Horn, 1990; Giros and Caron, 1993; Uhl et al., 1994). DA vesicular storage is performed by the vesicular monoamine transporter type 2 (VMAT2), also present in other monoaminergic cells (Miller et al., 1999). DAT may contribute to the vulnerability of DA-cells serving as an entrance for DA and its metabolites, while VMAT2 may serve as a neuroprotective factor by sequestering DA into vesicles, and preventing interaction with their catabolic enzymes. So, the functional balance between both transporters may affect the differential vulnerability between different midbrain DA-cell subpopulations. This idea is supported by the fact that VMAT2 deficient mice are more susceptible to MPTP than their homologous wild-type (Takahashi et al., 1997). Furthermore, they display spontaneous and progressive DA-cell degeneration (Caudle et al., 2007), and non-motor parkinsonian symptoms (Taylor et al., 2009), suggesting that VMAT2 may also be involved in the degeneration of other monoaminergic cells in PD. Studies carried out in our laboratory show that during normal aging, in parallel with the decline in vesicular DA uptake, VMAT2 is deglycosylated and moved from the vesicle membrane to the soluble compartment (Cruz-Muros et al., 2008), probably contributing to the increase of the vulnerability of DA-cells with age.

On the other hand, the damaging role of DAT is supported by the fact that its expression and functional integrity are required for making DA-cells susceptible to DA analog neurotoxins (Kopin, 1992; Gainetdinov et al., 1997; Bezard et al., 1999b), and by the report of an anatomical correlation between the distribution of DA-neurons expressing high DAT mRNA levels and those showing high vulnerability to degeneration in PD and animal models of PD (Cerruti et al., 1993; Hurd et al., 1994; Uhl et al., 1994). However, this correlation does not apply in some DA-cell groups. DA-cells in the parabrachialis pigmentosus region of the A10 cell group, which contain higher levels of DATmRNA than those in the dorsal tier of SN in monkeys (Haber et al., 1995) and rats (Shimada et al., 1992) are also more resistant to MPTP (Varastet et al., 1994) and 6-OHDA (Rodriguez et al., 2001) respectively. In addition, a comparative analysis of DAT and VMAT2 mRNA expressions in the ventral midbrain of rats revealed no differences between both mRNA expression patterns, with the highest levels in the SNrm, followed by the SNcv, and the lowest ones in VTA (GonzalezHernandez et al., 2004). So, the involvement of DA transporters 
in the differential vulnerability of DA-cells could be due to aspects other than differences in their mRNA levels. Given that DAT activity depends on its glycosylation status and membrane expression, we then explored a possible relationship between DAT glycosylation and function and the differential vulnerability of DA-cells (Afonso-Oramas et al., 2009). Glycosylated-DAT expression, DA uptake and DAT $V_{\max }$ were significantly higher in nigrostriatal neuron terminals than in those of mesolimbic neurons. These findings are consistent with those reporting that the number of ${ }^{3} \mathrm{H}$-DA uptake sites in the dSt is higher than in the vSt (Missale et al., 1985; Marshall et al., 1990; Cass et al., 1992), and correlate regional differences in DA uptake with the glycosylation status of DAT in both striatal compartments. Differences in DAT regulation may contribute to defining the pattern of DA time signaling and functional specialization in the dSt and vSt (Wickens et al., 2003). Interestingly, the expression pattern of glycosylated-DAT in the human midbrain and striatum showed a close anatomical relationship with DA-degeneration in parkinsonian patients. In addition, this relationship was confirmed in rodent and monkey models of PD, and in HEK-cells expressing the wild-type and a partially deglycosylated DAT form.

\section{CONCLUDING REMARKS}

Nearly two centuries after PD was first described by James Parkinson, its etiopathogenesis is still unknown. There is a tendency to consider $\mathrm{PD}$ as a multicausal disorder resulting from the convergence of environmental-, genetic-, and age-related factors. In recent years, mitochondrial dysfunction and proteostasis impairment have been proposed as having a leading role in the degenerative process. However, this idea contrasts with the selectivity of neuronal populations affected in PD. In spite of the large body of evidence supporting the participation of mitochondria and ER in the pathogenesis of PD, it is difficult to accept that a failure in functions common to

\section{REFERENCES}

Abou-Sleiman, P.M., Healy, D. G., Quinn, N., Lees, A. J., and Wood, N.W. (2003). The role of pathogenic DJ-1 mutations in Parkinson's disease. Ann. Neurol.54, 283-286.

Afonso-Oramas, D., Cruz-Muros, I., Alvarez de la Rosa, D., Abreu, P., Giraldez, T., Castro-Hernandez, J., Salas-Hernandez, J., Lanciego, J. L., Rodriguez, M., and GonzalezHernandez, T. (2009). Dopamine transporter glycosylation correlates with the vulnerability of midbrain dopaminergic cells in Parkinson's disease. Neurobiol. Dis. 36, 494-508.

Airaksinen, M. S., Thoenen, H., and Meyer, M. (1997). Vulnerability of midbrain dopaminergic neurons in calbindin-D28k-deficient mice: lack of evidence for a neuroprotective role of endogenous calbindin in MPTP-treated and weaver mice. Eur. J. Neurosci. 9, 120-127.

Alnemri, E. S. (2007). HtrA2 and Parkinson's disease: think PINK? Nat. Cell Biol. 9, 1227-1229.
Ashley, A. K., Hanneman, W.H., Katoh, T., Moreno, J. A., Pollack, A., Tjalkens, R. B., and Legare, M. E. (2009). Analysis of targeted mutation in DJ-1 on cellular function in primary astrocytes. Toxicol. Lett. 184, 186-191.

Baker, D. A., Xi, Z. X., Shen, H., Swanson, C. J., and Kalivas, P.W. (2002). The origin and neuronal function of in vivo nonsynaptic glutamate. J. Neurosci.22, 9134-9141.

Banati, R. B., Daniel, S. E., and Blunt, S. B. (1998). Glial pathology but absence of apoptotic nigral neurons in longstanding Parkinson's disease. Mov. Disord. 13, 221-227.

Barzilai, A., Melalmed, E., and Shirvan, A. (2001). Is there a rationale for neuroprotection against dopamine toxicity in Parkinson's disease. Cell. Mol. Neurobiol. 21, 215-235.

Bas, J., Calopa, M., Mestre, M., Mollevi, D. G., Cutillas, B., Ambrosio, S., and Buendia, E. (2001). Lymphocyte populations in Parkinson's disease and in rat models of parkinsonism. $J$. Neuroimmunol. 113, 146-152.

all cells is the main factor responsible for degeneration of particular neuronal groups. $\mathrm{Ca}^{2+}$-dependent pacemaking and DA handling are two oxidative stress generating activities specific to midbrain DA-cells. The reliance on $\mathrm{Ca}_{\mathrm{v}} 1.3 \mathrm{Ca}^{2+}$ channels to drive pacemaking and the pattern of DAT maturation and DA uptake also explain the differential susceptibility between nigrostriatal and mesolimbic neurons. Morphological and molecular studies performed in the last 20 years, with the aid of laser capture microdissection and more recently microarray analysis, show differences in the expression levels of more than 100 genes between vulnerable (nigrostriatal) and resistant (mesolimbic) DA-cells (Chung et al., 2005; Greene et al., 2005). These genes belong to different categories, including $\mathrm{Ca}^{2+}$ buffering proteins, mitochondrial proteins, L-type $\mathrm{Ca}^{2+}$ and inward rectifier $\mathrm{K}^{+}$channels, axon guidance and transcription factors, etc. (for review see Gonzalez-Hernandez et al., 2009). But the function and relevance of most of these in the differential vulnerability of DA-cells is still unknown.

Finally, we should not forget that, to a varying degree, other neuronal populations, such as noradrenergic neurons in the locus coeruleus, and cholinergic neurons in the dorsal nucleus of the vagus are also affected in $\mathrm{PD}$, and that $\mathrm{Ca}^{2+}$-dependent pacemaking and DA handling cannot explain their vulnerability. It would be interesting to elucidate whether there is a vulnerability factor common to all cell populations involved in $\mathrm{PD}$, or whether independent factors determine the start of the degenerative process in each neuronal group for their posterior convergence in a common pathogenic route.

\section{ACKNOWLEDGMENTS}

This work was partially supported by Ministerio de Ciencia e Innovación (grant no. BFU2007-66561) and CIBERNED (ISCIII). Josmar Salas-Hernandez and Javier Castro-Hernandez were supported by Fundación Canaria de Invetigación y Salud (FUNCIS).

Ben-Shachar, D., Riederer, P., and Youdim M.B. (1991). Iron-melanin interaction and lipid peroxidation: implications for Parkinson's disease. J. Neurochem 57, 1609-1614.

Benazzouz, A., Breit, S., Koudsie, A., Pollak, P., Krack, P., and Benabid, A. L. (2002). Intraoperative microrecordings of the subthalamic nucleus in Parkinson's disease. Mov. Disord. 17 (Suppl. 3), S145-S149.

Bender, A., Krishnan, K. J., Morris, C. M. Taylor, G. A., Reeve, A. K., Perry, R. H., Jaros, E., Hersheson, J. S., Betts, J., Klopstock, T., Taylor,R.W., and Turnbull, D. M. (2006). High levels of mitochondrial DNA deletions in substantia nigra neurons in aging and Parkinson disease. Nat. Genet. 38, 515-517.

Bennett, M. C. (2005). The role of alphasynuclein in neurodegenerative diseases. Pharmacol. Ther. 105, 311-331.

Bennett,M.C., Bishop,J.F.,Leng, Y., Chock, P. B., Chase, T. N., and Mouradian, M. M. (1999). Degradation of alphasynuclein by proteasome. J. Biol. Chem. 274, 33855-33858.
Bergman, H., Wichmann, T., Karmon, B., and DeLong, M. R. (1994). The primate subthalamic nucleus. II. Neuronal activity in the MPTP model of parkinsonism. J. Neurophysiol. 72, 507-520.

Berman, S. B., and Hasting, T. G. (1999). Dopamine oxidation alters mitochondrial respiration and induces permeability transition in brain mitochondria: implications for Parkinson's disease. J. Neurochem. 73, 1127-1137.

Berridge, M. J. (2002). The endoplasmic reticulum: a multifunctional signaling organelle. Cell Calcium 32, 235-249.

Betarbet, R., Sherer, T. B., MacKenzie, G., Garcia-Osuna, M., Panov, A. V., and Greenamyre, J. T. (2000). Chronic systemic pesticide exposure reproduces features of Parkinson's disease. Nat. Neurosci. 3, 1301-1306.

Bezard, E., Boraud, T., Bioulac, B., and Gross, C. E. (1999a). Involvement of the subthalamic nucleus in glutamatergic compensatory mechanisms. Eur. J. Neurosci. 11, 2167-2170. 
Bezard, E., Gross, C. E., Fournier, M. C., Dovero, S., Bloch, B., and Jaber, M. (1999b). Absence of MPTP-induced neuronal death in mice lacking the dopamine transporter. Exp. Neurol. $155,268-273$.

Biskup, S., Moore, D. J., Celsi, F., Higashi, S., West, A. B., Andrabi, S. A., Kurkinen, K., Yu, S. W., Savitt, J. M., Waldvogel, H. J., Faull, R. L., Emson, P. C., Torp, R., Ottersen, O. P., Dawson, T. M., and Dawson, V. L. (2006). Localization of LRRK2 to membranous and vesicular structures in mammalian brain. Ann. Neurol. 60, 557-569.

Blum, D., Torch, S., Lambeng, N., Nissou, M., Benabid, A. L., Sadoul, R., and Verna, J. M. (2001). Molecular pathways involved in the neurotoxicity of 6-OHDA, dopamine and MPTP: contribution to the apoptotic theory in Parkinson's disease. Prog. Neurobiol. 65, 135-172.

Blum-Degen, D., Muller, T., Kuhn, W., Gerlach, M., Przuntek, H., and Riederer, P. (1995). Interleukin-1 beta and interleukin- 6 are elevated in the cerebrospinal fluid of Alzheimer's and de novo Parkinson's disease patients. Neurosci. Lett. 202, 17-20.

Boka, G., Anglade, P., Wallach, D., JavoyAgid, F., Agid, Y., and Hirsch, E. C. (1994). Immunocytochemical analysis of tumor necrosis factor and its receptors in Parkinson's disease. Neurosci. Lett. 172, 151-154.

Bonifati, V., Rizzu, P., van Baren, M. J., Schaap, O., Breedveld, G. J., Krieger, E., Dekker, M. C., Squitieri, F., Ibanez, P., Joosse, M., van Dongen, J. W., Vanacore, N., van Swieten, J. C., Brice, A., Meco, G., van Duijn, C. M., Oostra, B. A., and Heutink, P. (2003). Mutations in the DJ-1 gene associated with autosomal recessive early-onset parkinsonism. Science 299, 256-259.

Borland, M. K., Mohanakumar, K. P., Rubinstein, J. D., Keeney, P. M., Xie, J., Capaldi, R., Dunham, L. D., Trimmer, P. A., and Bennett, J. P. Jr. (2009). Relationships among molecular genetic and respiratory properties of Parkinson's disease cybrid cells show similarities to Parkinson's brain tissues. Biochim. Biophys. Acta 1792, 68-74.

Bove, J., Prou, D., Perier, C., and Przedborski, S. (2005). Toxin-induced models of Parkinson's disease. NeuroRx $2,484-494$.

Braak, H., Del Tredici, K., Rub, U., de Vos, R. A., Jansen Steur, E. N., and Braak, E. (2003). Staging of brain pathology related to sporadic Parkinson's disease. Neurobiol. Aging 24, 197-211.

Burke, R. E., Dauer, W. T., and Vonsattel, J. P. (2008). A critical evaluation of the Braak staging scheme for Parkinson's disease. Ann. Neurol. 64, 485-491.
Burnashev, N., Monyer, H., Seeburg, P.H., and Sakmann, B. (1992). Divalent ion permeability of AMPA receptor channels is dominated by the edited form of a single subunit. Neuron 8, 189-198.

Cabello, C. R., Thune, J.J., Pakkenberg, H., and Pakkenberg, B. (2002). Ageing of substantia nigra in humans: cell loss may be compensated by hypertrophy. Neuropathol. Appl. Neurobiol. 28, 283-291.

Canet-Aviles, R. M., Wilson, M. A., Miller, D. W., Ahmad, R., McLendon, C., Bandyopadhyay, S., Baptista, M. J., Ringe, D., Petsko, G. A., and Cookson, M. R. (2004). The Parkinson's disease protein DJ-1 is neuroprotective due to cysteine-sulfinic acid-driven mitochondrial localization. Proc. Natl. Acad. Sci. U.S.A. 101, 9103-9108.

Cannon,J.R., Tapias, V., Na,H.M.,Honick, A. S., Drolet, R. E., and Greenamyre, J. T. (2009). A highly reproducible rotenone model of Parkinson's disease. Neurobiol. Dis. 34, 279-290.

Cass, W. A., Gerhardt, G. A., Mayfield, R. D., Curella, P., and Zahniser, N. R. (1992). Differences in dopamine clearance and diffusion in rat striatum and nucleus accumbens following systemic cocaine administration. J. Neurochem. 59, 259-266.

Caudle, W. M., Richardson, J. R., Wang, M. Z., Taylor, T. N., Guillot, T. S., McCormack, A. L., Colebrooke, R. E., Di Monte, D. A., Emson, P. C., and Miller, G. W. (2007). Reduced vesicular storage of dopamine causes progressive nigrostriatal neurodegeneration. J. Neurosci. 27, 8138-8148.

Cavelier, P., and Attwell, D. (2005). Tonic release of glutamate by a DIDSsensitive mechanism in rat hippocampal slices. J. Physiol. 564, 397-410.

Celsi, F., Pizzo, P., Brini, M., Leo, S., Fotino, C., Pinton, P., and Rizzuto, R. (2009). Mitochondria, calcium and cell death: a deadly triad in neurodegeneration. Biochim. Biophys. Acta 1787, 335-344.

Cerruti, C., Walther, D. M., Kuhar, M. J., and Uhl, G. R. (1993). Dopamine transporter mRNA expression is intense in rat midbrain neurons and modest outside midbrain. Brain Res. Mol. Brain Res. 18, 181-186.

Chan, C. S., Gertler, T. S., and Surmeier, D. J. (2009). Calcium homeostasis, selective vulnerability and Parkinson's disease. Trends Neurosci. 32, 249-256.

Chan, C. S., Guzman, J. N., Ilijic, E., Mercer, J. N., Rick, C., Tkatch, T., Meredith, G. E., and Surmeier, D. J. (2007). 'Rejuvenation' protects neurons in mouse models of Parkinson's disease. Nature 447, 1081-1086.

Charara, A., Smith, Y., and Parent, A. (1996). Glutamatergic inputs from the pedunculopontine nucleus to midbrain dopaminergic neurons in primates: phaseolus vulgarisleucoagglutinin anterograde labeling combined with postembedding glutamate and GABA immunohistochemistry. J. Comp. Neurol. 364, 254-266.

Choi, Y. M., Kim, S. H., Chung, S., Uhm, D. Y., and Park, M. K. (2006). Regional interaction of endoplasmic reticulum $\mathrm{Ca}^{2+}$ signals between soma and dendrites through rapid luminal $\mathrm{Ca}^{2+}$ diffusion. J. Neurosci. 26, 12127-12136.

Chung, C. Y., Seo, H., Sonntag, K. C., Brooks, A., Lin, L., and Isacson, O. (2005). Cell type-specific gene expression of midbrain dopaminergic neurons reveals molecules involved in their vulnerability and protection. Hum. Mol. Genet. 14 1709-1725.

Cicchetti, F., Drouin-Ouellet, J., and Gross, R. E. (2009). Environmental toxins and Parkinson's disease: what have we learned from pesticide-induced animal models? Trends Pharmacol. Sci. 30, 475-483.

Collier, T. J., Lipton, J., Daley, B. F., Palfi, S., Chu, Y., Sortwell, C., Bakay, R. A., Sladek, J. R., Jr., and Kordower, J. H. (2007). Aging-related changes in the nigrostriatal dopamine system and the response to MPTP in nonhuman primates: diminished compensatory mechanisms as a prelude to parkinsonism. Neurobiol. Dis. 26, 56-65.

Conn, P. J., and Pin, J. P. (1997). Pharmacology and functions of metabotropic glutamate receptors. Annu. Rev. Pharmacol. Toxicol. 37, 205-237.

Conway, K. A., Lee, S. J., Rochet, J. C., Ding, T. T., Williamson, R. E., and Lansbury, P. T. Jr. (2000). Acceleration of oligomerization, not fibrillization, is a shared property of both alpha-synuclein mutations linked to early-onset Parkinson's disease: implications for pathogenesis and therapy. Proc. Natl. Acad. Sci. U.S.A. 97, 571-576.

Cruz-Muros, I., Afonso-Oramas, D., Abreu, P., Barroso-Chinea, P. Rodriguez, M., Gonzalez, M. C., and Hernandez, T. G. (2007). Aging of the rat mesostriatal system: differences between the nigrostriatal and the mesolimbic compartments. Exp. Neurol. 204, 147-161.

Cruz-Muros, I., Afonso-Oramas, D., Abreu, P., Rodriguez, M., Gonzalez, M. C., and Gonzalez-Hernandez, T. (2008). Deglycosylation and subcellular redistribution of VMAT2 in the mesostriatal system during normal aging. Neurobiol. Aging 29 , 1702-1711.

Cuervo, A. M., Stefanis, L., Fredenburg, R., Lansbury, P. T., and Sulzer, D. (2004). Impaired degradation of mutant alpha-synuclein by chaperone-mediated autophagy. Science 305, 1292-1295.

D'Amato, R. J., Lipman, Z. P., and Snyder, S. H. (1986). Selectivity of the parkinsonian neurotoxin MPTP: toxic metabolite $\mathrm{MPP}^{+}$binds to neuromelanin. Science 231, 987-989.

Damier, P., Hirsch, E. C., Agid, Y., and Graybiel,A.M. (1999). The substantia nigra of the human brain. II. Patterns of loss of dopamine-containing neurons in Parkinson's disease. Brain 122(Pt 8), 1437-1448.

Darios, F., Corti, O., Lucking, C. B., Hampe, C., Muriel, M. P., Abbas, N., Gu, W. J., Hirsch, E. C., Rooney, T., Ruberg, M., and Brice, A. (2003). Parkin prevents mitochondrial swelling and cytochrome c release in mitochondria-dependent cell death. Hum. Mol. Genet. 12, 517-526.

Dauer, W., and Przedborski, S. (2003). Parkinson's disease: mechanisms and models. Neuron 39, 889-909.

de Lau, L. M., and Breteler, M. M. (2006). Epidemiology of Parkinson's disease. Lancet Neurol. 5, 525-535.

Dervan, A. G., Meshul, C. K., Beales, M., McBean, G. J., Moore, C., Totterdell, S., Snyder, A. K., and Meredith, G. E. (2004). Astroglial plasticity and glutamate function in a chronic mouse model of Parkinson's disease. Exp. Neurol. 190, 145-156.

Devi, L., Raghavendran, V., Prabhu, B. M., Avadhani, N. G., and Anandatheerthavarada, H. K. (2008). Mitochondrial import and accumulation of alpha-synuclein impair complex I in human dopaminergic neuronal cultures and Parkinson disease brain. J. Biol. Chem. 283, 9089-9100.

Dhillon, A. S., Tarbutton, G. L., Levin, J. L., Plotkin, G. M., Lowry, L. K., Nalbone, J.T., and Shepherd, S. (2008). Pesticide/environmental exposures and Parkinson's disease in East Texas. J. Agromedicine 13, 37-48.

Di Fonzo, A., Rohe, C. F., Ferreira, J., Chien, H. F., Vacca, L., Stocchi, F., Guedes, L., Fabrizio, E., Manfredi, M., Vanacore, N., Goldwurm, S., Breedveld, G., Sampaio, C., Meco, G., Barbosa, E., Oostra, B. A., and Bonifati, V. (2005). A frequent LRRK2 gene mutation associated with autosomal dominant Parkinson's disease. Lancet 365, 412-415.

Di Matteo, V., Pierucci, M., Di Giovanni, G., Di Santo, A., Poggi, A., Benigno, A. and Esposito, E. (2006). Aspirin protects striatal dopaminergic neurons from neurotoxin-induced degeneration: an in vivo microdialysis study. Brain Res. 1095, 167-177.

Di Monte, D., Jewell, S. A., Ekstrom, G., Sandy, M. S., and Smith, M. T. (1986a). 1-Methyl-4-phenyl-1,2,3,6tetrahydropyridine (MPTP) and 
1-methyl-4-phenylpyridine (MPP+) cause rapid ATP depletion in isolated hepatocytes. Biochem. Biophys. Res. Commun. 137, 310-315.

Di Monte, D., Sandy, M. S., Ekstrom, G., and Smith, M. T. (1986b). Comparative studies on the mechanisms of paraquat and 1-methyl-4phenylpyridine (MPP+) cytotoxicity. Biochem. Biophys. Res. Commun. 137, 303-309.

Enochs, W. S., Sarna, T., Zecca, L., Riley, P. A., and Swartz, H.M. (1994). The roles of neuromelanin, binding of metal ions, and oxidative cytotoxicity in the pathogenesis of Parkinson's disease: a hypothesis. J. Neural. Transm. Park. Dis. Dement. Sect. 7, 83-100.

Fasano, M., Bergamasco, B., and Lopiano, L. (2006). Modifications of ironneuromelanin system in Parkinson's disease. J. Neurochem. 96, 909-916.

Fearnley, J. M., and Lees, A. J. (1991). Ageing and Parkinson's disease: substantia nigra regional selectivity. Brain 114 (Pt 5), 2283-2301.

Firestone, J.A., Smith-Weller, T., Franklin, G., Swanson, P., Longstreth, W. T. Jr., and Checkoway, H. (2005). Pesticides and risk of Parkinson disease: a population-based case-control study. Arch. Neurol. 62, 91-95.

Foix, C., and Nicolesco, J. (1925). Anatomie cérébrale. Les noyaux gris centraux et la región Mésencéphalosous-optique., Suivi d'un apéndice sur l'anatomie pathologique de la maladie de Parkinson. Paris: Masson et Cie, pp. 508-538.

Forno, L. S. (1996). Neuropathology of Parkinson's disease. J. Neuropathol. Exp. Neurol. 55, 259-272.

Fornsted, B., Rosengren, E., and Carlsson, A. (1986). Occurrence and distribution of 5-S-cysteinyl derivates of dopamine, dopa and dopac in brains of eight mammalian species. Neuropharmacology 25 , 451-454.

Forster, G. L., and Blaha, C. D. (2003). Pedunculopontine tegmental stimulation evokes striatal dopamine efflux by activation of acetylcholine and glutamate receptors in the midbrain and pons of the rat. Eur. J. Neurosci. 17, 751-762.

Fredenburg, R.A., Rospigliosi,C., Meray, R. K., Kessler, J. C., Lashuel, H. A., Eliezer, D., and Lansbury, P. T. Jr. (2007). The impact of the E46K mutation on the properties of alpha-synuclein in its monomeric and oligomeric states. Biochemistry 46, 7107-7118.

Gainetdinov, R. R., Fumagalli, F., Jones, S. R., and Caron, M. G. (1997). Dopamine transporter is required for in vivo MPTP neurotoxicity: evidence from mice lacking the transporter. $J$. Neurochem. 69, 1322-1325.
Galluzzi, L., Blomgren, K., and Kroemer, G. (2009). Mitochondrial membrane permeabilization in neuronal injury. Nat. Rev. Neurosci. 10, 481-494.

Garcia, L., D’Alessandro, G., Fernagut, P. O., Bioulac, B., and Hammond, C. (2005). Impact of high-frequency stimulation parameters on the pattern of discharge of subthalamic neurons. $J$. Neurophysiol. 94, 3662-3669.

Gautier, C. A., Kitada, T., and Shen, J. (2008). Loss of PINK1 causes mitochondrial functional defects and increased sensitivity to oxidative stress. Proc. Natl. Acad. Sci. U.S.A. 105, 11364-11369.

Geiger, J. R., Melcher, T., Koh, D. S., Sakmann, B., Seeburg, P. H., Jonas, P., and Monyer, H. (1995). Relative abundance of subunit mRNAs determines gating and $\mathrm{Ca}^{2+}$ permeability of AMPA receptors in principal neurons and interneurons in rat CNS. Neuron 15, 193-204.

Gerfen, C. R., Baimbridge, K. G., and Miller, J. J. (1985). The neostriatal mosaic: compartmental distribution of calcium-binding protein and parvalbumin in the basal ganglia of the rat and monkey. Proc. Natl. Acad. Sci. U.S.A. $82,8780-8784$.

Gerfen, C. R., Herkenham, M., and Thibault, J. (1987). The neostriatal mosaic: II. Patch- and matrix-directed mesostriatal dopaminergic and nondopaminergic systems. J. Neurosci. 7, 3915-3934.

Gerhardt, G. A., Cass, W. A., Yi, A., Zhang, Z., and Gash, D. M. (2002). Changes in somatodendritic but not terminal dopamine regulation in aged rhesus monkeys. J. Neurochem. $80,168-177$.

German, D. C., Manaye, K., Smith, W. K., Woodward, D. J., and Saper, C. B. (1989). Midbrain dopaminergic cell loss in Parkinson's disease: computer visualization. Ann. Neurol. 26, 507-514.

German, D. C., Manaye, K. F., Sonsalla, P. K., and Brooks, B. A. (1992). Midbrain dopaminergic cell loss in Parkinson's disease and MPTP-induced parkinsonism: sparing of calbindin-D28kcontaining cells. Ann. N.Y. Acad. Sci. 648, 42-62.

Giasson, B. I., Covy, J. P., Bonini, N. M., Hurtig, H.I., Farrer, M. J., Trojanowski, J. Q., and Van Deerlin, V. M. (2006). Biochemical and pathological characterization of Lrrk2. Ann. Neurol. 59, 315-322.

Gibb, W. (1992). Melanin, tyrosine hydroxylase, calbindin and substance $\mathrm{P}$ in the human midbrain and substantia nigra in relation to nigrastriatal projections and differential neuron susceptibility in Parkinson's disease. Brain Res. 581, 283-291.
Gibb, W. R., and Lees, A. J. (1988). A comparison of clinical and pathological features of young- and old-onset Parkinson's disease. Neurology 38, 1402-1406.

Giros, B., and Caron, M. G. (1993). Molecular characterization of the dopamine transporter. Trends Pharmacol. Sci. 14, 43-49.

Gloeckner, C. J., Kinkl, N., Schumacher, A. Braun, R. J., O’Neill, E., Meitinger, T., Kolch, W., Prokisch, H., and Ueffing, M. (2006). The Parkinson disease causing LRRK2 mutation I2020T is associated with increased kinase activity. Hum. Mol. Genet. 15, 223-232.

Goldberg, M. S., Pisani, A., Haburcak, M. Vortherms, T. A., Kitada, T., Costa, C., Tong, Y., Martella, G., Tscherter, A., Martins, A., Bernardi, G., Roth, B. L., Pothos, E. N., Calabresi, P., and Shen, J. (2005). Nigrostriatal dopaminergic deficits and hypokinesia caused by inactivation of the familial Parkinsonism-linked gene DJ-1. Neuron 45, 489-496.

Gonzalez-Hernandez, T., Afonso-Oramas, D., and Cruz-Muros, I. (2009). Phenotype, compartmental organization and differential vulnerability of nigral dopaminergic neurons. $J$. Neural. Transm. Suppl.21-37.

Gonzalez-Hernandez, T., Barroso-Chinea, P., De La Cruz Muros, I., Del Mar Perez-Delgado, M., and Rodriguez, M. (2004). Expression of dopamine and vesicular monoamine transporters and differential vulnerability of mesostriatal dopaminergic neurons. J. Comp. Neurol. 479, 198-215.

Greene, J. G., Dingledine, R., and Greenamyre, J. T. (2005). Gene expression profiling of rat midbrain dopamine neurons: implications for selective vulnerability in parkinsonism. Neurobiol. Dis. 18, 19-31.

Greffard, S., Verny, M., Bonnet, A. M., Beinis, J. Y., Gallinari, C., Meaume, S., Piette, F., Hauw, J. J., and Duyckaerts, C. (2006). Motor score of the unified Parkinson disease rating scale as a good predictor of Lewy body-associated neuronal loss in the substantia nigra. Arch. Neurol. 63, 584-588.

Haas, R. H., Nasirian, F., Nakano, K., Ward, D., Pay, M., Hill, R., and Shults, C. W. (1995). Low platelet mitochondrial complex I and complex II/III activity in early untreated Parkinson's disease. Ann. Neurol. 37, 714-722.

Haber, S. N., Ryoo, H., Cox, C., and Lu, W. (1995). Subsets of midbrain dopaminergic neurons in monkeys are distinguished by different levels of mRNA for the dopamine transporter: comparison with the mRNA for the D2 receptor, tyrosine hydroxylase and calbindin immunoreactivity. J. Comp. Neurol. 362, 400-410.
Harman, D. (1956). Aging: a theory based on free radical and radiation chemistry. J. Gerontol. 11, 298-300.

Harrower, T. P., Michell, A. W., and Barker, R. A. (2005). Lewy bodies in Parkinson's disease: protectors or perpetrators? Exp. Neurol. 195, 1-6.

Hassler, R. (1938). Zur pathologie der paralysis agitans und des postencephalitschen Parkinsonismus. J. Psychol. Neurol. 48, 387-476.

Hasting, T. G. (1995). Enzymatic oxidation of dopamine: the role of prostaglandin H synthase. J. Neurochem. 64, 919-924.

Haycock, J. W., Becker, L., Ang, L., Furukawa, Y., Hornykiewicz, O. and Kish, S. J. (2003). Marked disparity between age-related changes in dopamine and other presynaptic dopaminergic markers in human striatum. J. Neurochem. 87, 574-585.

Hindle, J. V. (2010). Ageing, neurodegeneration and Parkinson's disease. Age Ageing 39, 156-161.

Hirsch, E., Graybiel, A., and Agid, Y. (1988). Melanized dopamine neurons are differentially susceptible to degeneration in Parkinson's disease. Nature 334, 345-348.

Hirsch, E. C., and Hunot, S. (2009). Neuroinflammation in Parkinson's disease: a target for neuroprotection? Lancet Neurol. 8, 382-397.

Hisanaga, K., Asagi, M., Itoyama, Y., and Iwasaki, Y. (2001). Increase in peripheral CD4 bright+ CD8 +dull T cells in Parkinson disease. Arch. Neurol. 58, 1580-1583.

Hoglinger, G. U., Feger, J., Prigent, A., Michel, P. P., Parain, K., Champy, P., Ruberg, M., Oertel, W.H., and Hirsch, E. C. (2003). Chronic systemic complex I inhibition induces a hypokinetic multisystem degeneration in rats. $J$. Neurochem. 84, 491-502.

Hollmann, M., and Heinemann, S. (1994). Cloned glutamate receptors. Annu. Rev. Neurosci. 17, 31-108.

Horn, A. S. (1990). Dopamine uptake: a review of progress in the last decade. Prog. Neurobiol. 34, 387-400.

Hornykiewicz, O. (2006). The discovery of dopamine deficiency in the parkinsonian brain. J. Neural Transm. Suppl. 70, 9-15.

Hosoi, T., and Ozawa, K. (2009). Endoplasmic reticulum stress in disease: mechanisms and therapeutic opportunities. Clin. Sci. (Lond) 118 , 19-29.

Hsu, L. J., Sagara, Y., Arroyo, A., Rockenstein, E., Sisk, A., Mallory, M., Wong, J., Takenouchi, T., Hashimoto, M., and Masliah, E. (2000). alphasynuclein promotes mitochondrial deficit and oxidative stress. Am. J. Pathol. 157, 401-410. 
Hunot, S., Boissiere, F., Faucheux, B., Brugg, B., Mouatt-Prigent, A., Agid, Y., and Hirsch, E. C. (1996). Nitric oxide synthase and neuronal vulnerability in Parkinson's disease. Neuroscience 72, 355-363.

Hurd, Y. L., Pristupa, Z. B., Herman, M. M., Niznik, H. B., and Kleinman, J. E. (1994). The dopamine transporter and dopamine $\mathrm{D} 2$ receptor messenger RNAs are differentially expressed in limbic- and motor-related subpopulations of human mesencephalic neurons. Neuroscience 63, 357-362.

Hurley, S. D., O'Banion, M. K., Song, D. D., Arana, F. S., Olschowka, J. A., and Haber, S. N. (2003). Microglial response is poorly correlated with neurodegeneration following chronic, low-dose MPTP administration in monkeys. Exp. Neurol. 184, 659-668.

Iaccarino, C., Crosio, C., Vitale, C., Sanna, G., Carri, M. T., and Barone, P. (2007). Apoptotic mechanisms in mutant LRRK2-mediated cell death. Hum. Mol. Genet. 16, 1319-1326.

Imai, Y., Soda, M., Inoue, H., Hattori, N., Mizuno, Y., and Takahashi, R. (2001). An unfolded putative transmembrane polypeptide, which can lead to endoplasmic reticulum stress, is a substrate of Parkin. Cell 105, 891-902.

Imamura, K., Hishikawa, N., Sawada, M., Nagatsu, T., Yoshida, M., and Hashizume, Y. (2003). Distribution of major histocompatibility complex class II-positive microglia and cytokine profile of Parkinson's disease brains. Acta Neuropathol. 106, 518-526.

Iribe, Y., Moore, K., Pang, K. C., and Tepper, J. M. (1999). Subthalamic stimulationinduced synaptic responses in substantia nigra pars compacta dopaminergic neurons in vitro. J. Neurophysiol. 82, 925-933.

Irwin, I., DeLanney, L. E., McNeill, T., Chan, P., Forno, L. S., Murphy, G. M., Jr., Di Monte, D. A., Sandy, M. S., and Langston, J. W. (1994). Aging and the nigrostriatal dopamine system: a non-human primate study. Neurodegeneration 3, 251-265.

Jellinger, K. A. (2009). Recent advances in our understanding of neurodegeneration. J. Neural. Transm. 116, 1111-1162.

Jenner, P. (2003). Oxidative stress in Parkinson's disease. Ann. Neurol. 53 (Suppl. 3), S26-S36; discussion S28-S36.

Joglar, B., Rodriguez-Pallares, J., Rodriguez-Perez, A. I., Rey, P., Guerra, M. J., and Labandeira-Garcia. J. L. (2009). The inflammatory response in the MPTP model of Parkinson's disease is mediated by brain angiotensin: relevance to progression of the disease. J. Neurochem. 109, 656-669.
Jonsson, G. (1971). Quantitation of fluorescence of biogenic monoamines. Prog. Histochem. Cytochem. 2, 244-299.

Keeney, P. M., Xie, J., Capaldi, R. A., and Bennett, J.P. Jr. (2006). Parkinson's disease brain mitochondrial complex I has oxidatively damaged subunits and is functionally impaired and misassembled. J. Neurosci. 26, 5256-5264.

Kim, R. H., Smith, P. D., Aleyasin, H., Hayley, S., Mount, M. P., Pownall, S., Wakeham, A., You-Ten, A. J., Kalia, S. K., Horne, P., Westaway, D., Lozano, A. M., Anisman, H., Park, D. S., and Mak, T.W. (2005). Hypersensitivity of DJ-1deficient mice to 1-methyl-4-phenyl1,2,3,6-tetrahydropyrindine (MPTP) and oxidative stress. Proc. Natl. Acad. Sci. U.S.A. 102, 5215-5220.

Kim, Y., Park, J., Kim, S., Song, S., Kwon, S. K., Lee, S. H., Kitada, T., Kim, J. M., and Chung, J. (2008). PINK1 controls mitochondrial localization of Parkin through direct phosphorylation. Biochem. Biophys. Res. Commun. 377, 975-980.

Kish, S. J., Shannak, K., Rajput, A., Deck, J. H., and Hornykiewicz, O. (1992). Aging produces a specific pattern of striatal dopamine loss: implications for the etiology of idiopathic Parkinson's disease. J. Neurochem. 58 , 642-648.

Kita, H., and Kitai, S. T. (1987). Efferent projections of the subthalamic nucleus in the rat: light and electron microscopic analysis with the PHA-L method. J. Comp. Neurol. 260, 435-452.

Kitada, T., Asakawa, S., Hattori, N., Matsumine, H., Yamamura, Y., Minoshima, S., Yokochi, M., Mizuno, Y., and Shimizu, N. (1998). Mutations in the parkin gene cause autosomal recessive juvenile parkinsonism. Nature 392, 605-608.

Knott, C., Stern, G., and Wilkin, G. P. (2000). Inflammatory regulators in Parkinson's disease: iNOS, lipocortin- 1 , and cyclooxygenases- 1 and -2 . Mol. Cell. Neurosci. 16, 724-739.

Kopin, I. J. (1992). Features of the dopaminergic neurotoxin MPTP. Ann. N. Y. Acad. Sci. 648, 96-104.

Kraytsberg, Y., Kudryavtseva, E., McKee, A. C., Geula, C., Kowall, N. W., and Khrapko, K. (2006). Mitochondrial DNA deletions are abundant and cause functional impairment in aged human substantia nigra neurons. Nat. Genet. 38, 518-520.

Krige, D., Carroll, M. T., Cooper, J. M., Marsden, C. D., and Schapira, A. H. (1992). Platelet mitochondrial function in Parkinson's disease. The Royal Kings and Queens Parkinson Disease Research Group. Ann. Neurol. 32, 782-788.
Kroemer, G., and Blomgren, K. (2007) Mitochondrial cell death contro in familial Parkinson disease. PLoS Biol. 5, e206. doi: 10.1371/journal. pbio.0050206.

Kubis, N., Faucheux, B. A., Ransmayr, G., Damier, P., Duyckaerts, C., Henin, D. Forette, B., Le Charpentier, Y., Hauw, J. J., Agid, Y., and Hirsch, E. C. (2000) Preservation of midbrain catecholaminergic neurons in very old human subjects. Brain 123 (Pt 2), 366-373.

Kuhn, D. M., Francescutti-Verbeem, D. M., and Thomas, D. M. (2006). Dopamine quinones activate microglia and induce a neurotoxic gene expression profile: relationship to methamphetamine-induced nerve ending damage. Ann. N.Y. Acad. Sci. 1074, 31-41.

Kurkowska-Jastrzebska, I., Babiuch, M., Joniec, I., Przybylkowski, A., Czlonkowski, A., and Czlonkowska, A. (2002). Indomethacin protects against neurodegeneration caused by MPTP intoxication in mice. Int Immunopharmacol. 2, 1213-1218.

Kuroda, Y., Mitsui, T., Kunishige, M., and Matsumoto, T. (2006). Parkin affects mitochondrial function and apoptosis in neuronal and myogenic cells. Biochem. Biophys. Res. Commun. 348 787-793.

LaFerla, F. M. (2002). Calcium dyshomeostasis and intracellular signalling in Alzheimer's disease. Nat. Rev. Neurosci. 3, 862-872.

Langston, J. W., Ballard, P., Tetrud, J. W., and Irwin, I. (1983). Chronic Parkinsonism in humans due to a product of meperidine-analog synthesis. Science 219, 979-980.

Lapointe, N.,St-Hilaire, M., Martinoli, M. G., Blanchet, J., Gould, P., Rouillard, C., and Cicchetti, F. (2004). Rotenone induces non-specific central nervous system and systemic toxicity. FASEB J. 18, 717-719

Lashuel, H. A., Petre, B. M., Wall, J., Simon, M., Nowak, R. J., Walz, T. and Lansbury, P. T. Jr. (2002). Alphasynuclein, especially the Parkinson's disease-associated mutants, forms pore-like annular and tubular protofibrils. J. Mol. Biol. 322, 1089-1102.

LaVoie, M. J., Ostaszewski, B. L., Weihofen, A., Schlossmacher, M. G., and Selkoe, D. J. (2005). Dopamine covalently modifies and functionally inactivates parkin. Nat. Med. 11, 1214-1221.

Lee, C. R., and Tepper, J. M. (2009). Basal ganglia control of substantia nigra dopaminergic neurons. J. Neural. Transm. Suppl. 71-90.

Lee, S. J., Kim, S. J., Kim, I. K., Ko, J., Jeong, C. S., Kim, G. H., Park, C., Kang, S. O., Suh, P. G., Lee, H. S., and Cha, S. S. (2003). Crystal structures of human DJ-1 and Escherichia coli Hsp31, which share an evolutionarily conserved domain. J. Biol. Chem. 278, 44552-44559.

Leroy, E., Boyer, R., Auburger, G., Leube, B., Ulm, G., Mezey, E., Harta, G., Brownstein, M. J., Jonnalagada, S., Chernova, T., Dehejia, A., Lavedan, C., Gasser, T., Steinbach, P. J., Wilkinson, K. D., and Polymeropoulos, M. H. (1998). The ubiquitin pathway in Parkinson's disease. Nature 395, 451-452.

Liang, C. L., Sinton, C. M., and German, D. C. (1996). Midbrain dopaminergic neurons in the mouse: co-localization with Calbindin-D28K and calretinin. Neuroscience 75, 523-533.

Liberatore, G. T., Jackson-Lewis, V., Vukosavic, S., Mandir, A. S., Vila, M., McAuliffe, W. G., Dawson, V. L., Dawson, T. M., and Przedborski, S. (1999). Inducible nitric oxide synthase stimulates dopaminergic neurodegeneration in the MPTP model of Parkinson disease. Nat. Med. 5 , 1403-1409.

Limousin, P., Krack, P., Pollak, P., Benazzouz, A., Ardouin, C., Hoffmann, D., and Benabid,A.L. (1998). Electrical stimulation of the subthalamic nucleus in advanced Parkinson's disease. $N$. Engl. J. Med. 339, 1105-1111.

Lindquist, N. G., Larsson, B. S., and Lydén-Sokolowski, A. (1988). Autoradiography of [14C] paraquat or $[14 \mathrm{C}]$ diquat in frogs and mice: accumulation in neuromelanin. Neurosci. Lett. 93, 1-6.

Liou, H. H., Tsai, M. C., Chen, C. J., Jeng, J. S., Chang, Y. C., Chen, S. Y., and Chen, R. C. (1997). Environmental risk factors and Parkinson's disease: a casecontrol study in Taiwan. Neurology 48 , 1583-1588.

Lippa, C. F., Duda, J. E., Grossman, M., Hurtig, H. I., Aarsland, D., Boeve, B. F., Brooks, D. J., Dickson, D. W., Dubois, B., Emre, M., Fahn, S., Farmer, J. M., Galasko, D., Galvin, J. E., Goetz, C. G. Growdon, J. H., Gwinn-Hardy, K. A., Hardy, J., Heutink, P., Iwatsubo, T., Kosaka, K., Lee, V. M., Leverenz, J. B., Masliah, E., McKeith, I. G., Nussbaum, R. L., Olanow, C. W., Ravina, B. M., Singleton, A. B., Tanner, C. M., Trojanowski, J. Q., and Wszolek, Z. K. (2007). DLB and PDD boundary issues: diagnosis, treatment, molecular pathology, and biomarkers. Neurology $68,812-819$.

Lohmann, E., Periquet, M., Bonifati, V., Wood, N. W., De Michele, G., Bonnet, A. M., Fraix, V., Broussolle, E., Horstink, M. W., Vidailhet, M., Verpillat, P., Gasser, T., Nicholl, D., Teive, H., Raskin, S., Rascol, O., Destee, A., Ruberg, M., Gasparini, F., Meco, G., Agid, Y., Durr, A., and Brice, A. (2003). How much phenotypic variation can 
be attributed to parkin genotype? Ann Neurol. 54, 176-185.

Mak, S. K., McCormack, A. L., ManningBog, A. B., Cuervo, A. M., and Di Monte, D. A. (2010). Lysosomal degradation of alpha-synuclein in vivo. $J$. Biol. Chem. 285, 13621-13629.

Mann, D., and Yates, P. (1983). Possible role of neuromelanin in the pathogenesis of Parkinson's disease. Mech. Ageing Dev. 21, 193-203.

Manning-Bog, A. B., McCormack, A. L., Purisai, M. G., Bolin, L. M., and Di Monte, D. A. (2003). Alpha-synuclein overexpression protects against paraquat-induced neurodegeneration. J. Neurosci. 23, 3095-3099.

Marshall, J. F., O'Dell, S. J., Navarrete, R., and Rosenstein,A.J.(1990).Dopamine high-affinity transport site topography in rat brain: major differences between dorsal and ventral striatum. Neuroscience 37, 11-21.

Martin, L. J., Pan, Y., Price, A. C., Sterling, W., Copeland, N. G., Jenkins, N. A., Price, D. L., and Lee, M. K. (2006). Parkinson's disease alpha-synuclein transgenic mice develop neuronal mitochondrial degeneration and cell death. J. Neurosci. 26, 41-50.

McCormack, A. L., Di Monte, D. A., Delfani, K., Irwin, I., DeLanney, L. E., Langston, W. J., and Janson, A. M. (2004). Aging of the nigrostriatal system in the squirrel monkey. J. Comp. Neurol. 471, 387-395.

McCormack, A. L., Thiruchelvam, M., Manning-Bog, A. B., Thiffault, C., Langston, J. W., Cory-Slechta, D. A., and Di Monte, D. A. (2002). Environmental risk factors and Parkinson's disease: selective degeneration of nigral dopaminergic neurons caused by the herbicide paraquat. Neurobiol. Dis. 10, 119-127.

McCormack, J. G., Halestrap, A. P., and Denton, R. M. (1990). Role of calcium ions in regulation of mammalian intramitochondrial metabolism. Physiol. Rev. 70, 391-425.

McGeer, P. L., Itagaki, S., Akiyama, H., and McGeer,E. G. (1988). Rate of cell death in parkinsonism indicates active neuropathological process. Ann. Neurol. 24, 574-576.

McGeer, P. L., and McGeer, E. G. (2004). Inflammation and the degenerative diseases of aging. Ann. N. Y. Acad. Sci. 1035, 104-116.

McGeer, P. L., McGeer, E. G., and Suzuki, J.S. (1977). Aging and extrapyramidal function. Arch. Neurol. 34, 33-35.

McGeer, P. L., Schwab, C., Parent, A., and Doudet, D. (2003). Presence of reactive microglia in monkey substantia nigra years after 1-methyl-4-phenyl-1,2,3,6tetrahydropyridine administration. Ann. Neurol. 54, 599-604.
McNaught, K. S., Belizaire, R., Isacson, O., Jenner, P., and Olanow, C. W. (2003). Altered proteasomal function in sporadic Parkinson's disease. Exp. Neurol. 179, 38-46.

McNaught, K. S., Belizaire, R., Jenner, P., Olanow, C. W., and Isacson, O. (2002a). Selective loss of 20 S proteasome alpha-subunits in the substantia nigra pars compacta in Parkinson's disease. Neurosci. Lett. 326, 155-158.

McNaught, K. S., Jnobaptiste, R., Jackson, T., and Jengelley, T. A. (2010). The pattern of neuronal loss and survival may reflect differential expression of proteasome activators in Parkinson's disease. Synapse 64, 241-250.

McNaught, K. S., Olanow, C. W., Halliwell, B., Isacson, O., and Jenner, P. (2001). Failure of the ubiquitin-proteasome system in Parkinson's disease. Nat. Rev. Neurosci. 2, 589-594.

McNaught, K. S., Shashidharan, P., Perl, D. P., Jenner, P., and Olanow, C. W. (2002b). Aggresome-related biogenesis of Lewy bodies. Eur. J. Neurosci. 16, 2136-2148.

McRitchie, D. A., and Halliday, G. M. (1995). Calbindin D28k-containing neurons are restricted to the medial substantia nigra in humans. Neuroscience 65, 87-91.

McRitchie, D. A., Hardman, C. D., and Halliday, G. M. (1996). Cytoarchitectural distribution of calcium binding proteins in midbrain dopaminergic regions of rats and humans. J. Comp. Neurol. 364, 121-150.

Miller, G.W. (2007). Paraquat: the red herring of Parkinson's disease research. Toxicol. Sci. 100, 1-2.

Miller, G. W., Gainetdinov, R. R., Levey, A. I., and Caron, M. G. (1999). Dopamine transporters and neuronal injury. Trends Pharmacol. Sci. 20, 424-429.

Missale, C., Castelletti, L., Govoni, S., Spano, P. F., Trabucchi, M., and Hanbauer, I. (1985). Dopamine uptake is differentially regulated in rat striatum and nucleus accumbens. J. Neurochem. 45, 51-56.

Miyazaki, I., and Asanuma, M. (2009). Approaches to prevent dopamine quinone-induced neurotoxicity. Neurochem. Res. 34, 698-706.

Mizuno, Y., Sone, N., Suzuki, K., and Saitoh, T. (1988). Studies on the toxicity of 1-methyl-4-phenylpyridinium ion (MPP+) against mitochondria of mouse brain. J. Neurol. Sci. 86, 97-110.

Mogi, M., Harada, M., Kondo, T., Riederer, P., Inagaki, H., Minami, M., and Nagatsu, T. (1994a). Interleukin-1 beta, interleukin-6, epidermal growth factor and transforming growth factor-alpha are elevated in the brain from parkinsonian patients. Neurosci. Lett. 180, 147-150.

Mogi, M., Harada, M., Riederer, P., Narabayashi, H., Fujita, K., and Nagatsu, T. (1994b). Tumor necrosis factor-alpha (TNF-alpha) increases both in the brain and in the cerebrospinal fluid from parkinsonian patients. Neurosci. Lett. 165, 208-210.

Mogi, M., Togari, A., Kondo, T., Mizuno, Y., Komure, O., Kuno, S., Ichinose, H., and Nagatsu, T. (2000). Caspase activities and tumor necrosis factor receptor R1 (p55) level are elevated in the substantia nigra from parkinsonian brain. J. Neural. Transm. 107 335-341.

Muñoz, A., Rey, P., Guerra, M. J., Mendez-Alvarez, E., Soto-Otero, R. and Labandeira-Garcia, J. L. (2006) Reduction of dopaminergic degeneration and oxidative stress by inhibition of angiotensin converting enzyme in a MPTP model of parkinsonism. Neuropharmacology 51, 112-120.

Murakami, T., Shoji, M., Imai, Y., Inoue, H., Kawarabayashi, T., Matsubara, E., Harigaya, Y., Sasaki, A., Takahashi, R. and Abe, K. (2004). Pael-R is accumulated in Lewy bodies of Parkinson's disease. Ann. Neurol. 55, 439-442.

Nicklas, W. J., Vyas, I., and Heikkila, R. E. (1985). Inhibition of NADH-linked oxidation in brain mitochondria by 1-methyl-4-phenyl-pyridine, a metabolite of the neurotoxin, 1-methyl-4phenyl-1,2,5,6-tetrahydropyridine. Life Sci. 36, 2503-2508.

Nishikawa, K., Li, H., Kawamura, R., Osaka, H., Wang, Y. L., Hara, Y. Hirokawa, T., Manago, Y., Amano, T., Noda, M., Aoki, S., and Wada, K. (2003). Alterations of structure and hydrolase activity of parkinsonismassociated human ubiquitin carboxyl-terminal hydrolase L1 variants. Biochem. Biophys. Res. Commun. 304 176-183.

Novelli, A., Reilly, J. A., Lysko, P. G., and Henneberry, R. C. (1988). Glutamate becomes neurotoxic via the $\mathrm{N}$-methylD-aspartate receptor when intracellular energy levels are reduced. Brain Res. $451,205-212$

Nussbaum, R. L., and Ellis, C. E. (2003). Alzheimer's disease and Parkinson's disease. N. Engl. J. Med. 348 1356-1364.

Olanow, C. W., and McNaught, K. S. (2006). Ubiquitin-proteasome system and Parkinson's disease. Mov. Disord. 21, 1806-1823.

Olzmann, J. A., Brown, K., Wilkinson, K. D., Rees, H. D., Huai, Q., Ke, H. Levey, A. I., Li, L., and Chin, L. S. (2004). Familial Parkinson's diseaseassociated L166P mutation disrupts DJ-1 protein folding and function. $J$. Biol. Chem. 279, 8506-8515.
Omelchenko, N., and Sesack, S. R. (2005). Laterodorsal tegmental projections to identified cell populations in the rat ventral tegmental area. J. Comp. Neurol. 483, 217-235.

Paisan-Ruiz, C., Jain, S., Evans, E. W. Gilks, W. P., Simon, J., van der Brug, M., Lopez de Munain, A., Aparicio, S., Gil, A. M., Khan, N., Johnson, J. Martinez, J. R., Nicholl, D., Carrera, I. M., Pena, A. S., de Silva, R., Lees, A., Marti-Masso, J. F., Perez-Tur, J., Wood, N. W., and Singleton, A. B. (2004). Cloning of the gene containing mutations that cause PARK8linked Parkinson's disease. Neuron 44, 595-600.

Pakkenberg, H., Andersen, B. B., Burns, R. S., and Pakkenberg, B. (1995). A stereological study of substantia nigra in young and old rhesus monkeys. Brain Res. 693, 201-206.

Palacino, J. J., Sagi, D., Goldberg, M. S., Krauss, S., Motz, C., Wacker, M., Klose, J., and Shen, J. (2004). Mitochondrial dysfunction and oxidative damage in parkin-deficient mice. J. Biol. Chem. 279, 18614-18622.

Pan, T., Kondo, S., Le, W., and Jankovic J. (2008). The role of autophagylysosome pathway in neurodegeneration associated with Parkinson's disease. Brain 131, 1969-1978.

Parker, W. D. Jr., Parks, J.K., and Swerdlow, R. H. (2008). Complex I deficiency in Parkinson's disease frontal cortex. Brain Res. 1189, 215-218.

Paschen, W., and Mengesdorf, T. (2005). Endoplasmic reticulum stress response and neurodegeneration. Cell Calcium $38,409-415$.

Pearce, R. K., Hawkes, C. H., and Daniel, S. E. (1995). The anterior olfactory nucleus in Parkinson's disease. Mov. Disord. 10, 283-287.

Pickart, C. M. (2004). Back to the future with ubiquitin. Cell 116, 181-190.

Plaitakis, A., and Shashidharan, P. (2000). Glutamate transport and metabolism in dopaminergic neurons of substantia nigra: implications for the pathogenesis of Parkinson's disease. J. Neurol. 247 (Suppl. 2), II25-II35.

Polymeropoulos, M.H.,Lavedan, C., Leroy, E., Ide, S. E., Dehejia, A., Dutra, A., Pike, B., Root, H., Rubenstein, J., Boyer, R., Stenroos, E. S., Chandrasekharappa, S. Athanassiadou, A., Papapetropoulos, T., Johnson, W. G., Lazzarini, A. M., Duvoisin, R. C., Di Iorio, G., Golbe, L. I., and Nussbaum, R. L. (1997) Mutation in the alpha-synuclein gene identified in families with Parkinson's disease. Science 276, 2045-2047.

Poon, H. F., Frasier, M., Shreve, N., Calabrese, V., Wolozin, B. and Butterfield, D. A. (2005). Mitochondrial associated metabolic proteins are selectively oxidized in 
A30P alpha-synuclein transgenic mice--a model of familial Parkinson's disease. Neurobiol. Dis. 18, 492-498.

Pridgeon, J. W., Olzmann, J. A., Chin, L. S., and Li, L. (2007). PINK1 protects against oxidative stress by phosphorylating mitochondrial chaperone TRAP1. PLoS Biol. 5, e172. doi: 10.1371/journal.pbio.0050172.

Przedborski, S., and Jackson-Lewis, V. (1998). Mechanisms of MPTP toxicity. Mov. Disord. 13 (Suppl. 1), 35-38.

Ramirez,A., Heimbach, A., Grundemann, J., Stiller, B., Hampshire, D., Cid, L. P., Goebel, I., Mubaidin, A. F., Wriekat, A. L., Roeper, J., Al-Din, A., Hillmer, A. M., Karsak, M., Liss, B., Woods, C. G., Behrens, M. I., and Kubisch, C. (2006). Hereditary parkinsonism with dementia is caused by mutations in ATP13A2, encoding a lysosomal type 5 P-type ATPase. Nat. Genet. 38, 1184-1191.

Rizzuto, R., and Pozzan, T. (2006). Microdomains of intracellular $\mathrm{Ca}^{2+}$ : molecular determinants and functional consequences. Physiol. Rev. 86, 369-408.

Rochet, J.C., Outeiro, T. F., Conway, K. A., Ding, T. T., Volles, M. J., Lashuel, H. A., Bieganski, R. M., Lindquist, S. L., and Lansbury, P. T. (2004). Interactions among alpha-synuclein, dopamine, and biomembranes: some clues for understanding neurodegeneration in Parkinson's disease. J. Mol. Neurosci. 23, 23-34

Rodriguez, M.,Barroso-Chinea, P., Abdala, P., Obeso, J., and Gonzalez-Hernandez, T. (2001). Dopamine cell degeneration induced by intraventricular administration of 6-hydroxydopamine in the rat: similarities with cell loss in parkinson's disease. Exp. Neurol. 169, 163-181.

Rodriguez-Pallares, J., Rey, P., Parga, J. A., Muñoz, A., Guerra, M. J., and Labandeira-Garcia, J. L. (2008).Brain angiotensin enhances dopaminergic cell death via microglial activation and NADPH-derived ROS. Neurobiol. Dis. 31, 58-73.

Saito, Y., Ruberu, N. N., Sawabe, M., Arai, T., Kazama, H., Hosoi, T., Yamanouchi, H., and Murayama, S. (2004). Lewy body-related alpha-synucleinopathy in aging. J. Neuropathol. Exp. Neurol. $63,742-749$.

Salazar, M., Sokoloski, T. D., and Patil, P. N. (1978). Binding of dopaminergic drugs by the neuromelanin of the substantia nigra, synthetic melanins and melanin granules. Fed. Proc. 37, 2403-2407.

Sanchez-Ferrer, A., Rodriguez-Lopez, J. N., Garcia-Canovas, F., and GarciaCarmona, F. (1995). Tyrosinase: a comprehensive review of its mechanism. Biochim. Biophys. Acta. 1247, 1-11.
Schapira, A. H. (2008). Mitochondria in the aetiology and pathogenesis of Parkinson's disease. Lancet Neurol. 7, 97-109.

Schapira, A. H., Cooper, J. M., Dexter, D., Clark, J. B., Jenner, P., and Marsden, C. D. (1990). Mitochondrial complex I deficiency in Parkinson's disease. J. Neurochem. 54, 823-827.

Schon, E. A., and Manfredi, G. (2003). Neuronal degeneration and mitochondrial dysfunction. J. Clin. Invest. $111,303-312$.

Schuler, F., and Casida, J. E. (2001). The insecticide target in the PSST subunit of complex I. Pest. Manag. Sci. 57, 932-940.

Schultz, W. (2002). Getting formal with dopamine and reward. Neuron 36, 241-263.

Semchuk, K. M., Love, E. J., and Lee, R. G. (1992). Parkinson's disease and exposure to agricultural work and pesticide chemicals. Neurology 42, 1328-1335.

Shah, I. M., and Di Napoli, M. (2007). The ubiquitin-proteasome system and proteasome inhibitors in central nervous system diseases. Cardiovasc. Hematol. Disord. Drug Targets 7, 250-273.

Shendelman, S., Jonason, A., Martinat, C., Leete, T., and Abeliovich, A. (2004). DJ-1 is a redox-dependent molecular chaperone that inhibits alphasynuclein aggregate formation. PLoS Biol. 2, e362. doi: 10.1371/journal. pone. 0001884 .

Sherer, T. B., Kim, J. H., Betarbet, R., and Greenamyre,J.T.(2003).Subcutaneous rotenone exposure causes highly selective dopaminergic degeneration and alpha-synuclein aggregation. Exp. Neurol. 179, 9-16.

Shima, T., Sarna, T., Swartz, H. M., Stroppolo, A., Gerbasi, R., and Zecca, L. (1997). Binding of iron to neuromelanin of human substantia nigra and synthetic melanin: an electron paramagnetic resonance spetroscopy study. Free Radic. Biol. Med. $23,110-119$.

Shimada, S., Kitayama, S., Walther, D., and Uhl, G. (1992). Dopamine transporter mRNA: dense expression in ventral midbrain neurons. Brain Res. Mol. Brain Res. 13, 359-362.

Shimura, H., Hattori, N., Kubo, S., Yoshikawa, M., Kitada, T., Matsumine, H., Asakawa, S., Minoshima, S., Yamamura, Y., Shimizu, N., and Mizuno, Y. (1999). Immunohistochemical and subcellular localization of Parkin protein: absence of protein in autosomal recessive juvenile parkinsonism patients. Ann. Neurol. 45, 668-672.

Silvestri, L., Caputo, V., Bellacchio, E., Atorino, L., Dallapiccola, B., Valente, E. M., and Casari, G. (2005). Mitochondrial import and enzymatic activity of PINK1 mutants associated to recessive parkinsonism. Hum. Mol Genet. 14, 3477-3492.

Singleton, A. B., Farrer, M., Johnson, J., Singleton, A., Hague, S., Kachergus, J., Hulihan, M., Peuralinna, T., Dutra, A. Nussbaum, R., Lincoln, S., Crawley, A. Hanson, M., Maraganore, D., Adler, C. Cookson, M. R., Muenter, M., Baptista, M., Miller, D., Blancato, J., Hardy, J., and Gwinn-Hardy, K. (2003). alphaSynuclein locus triplication causes Parkinson's disease. Science 302, 841.

Snyder, H., Mensah, K., Theisler, C., Lee, J., Matouschek, A., and Wolozin, B. (2003). Aggregated and monomeric alpha-synuclein bind to the S6' proteasomal protein and inhibit proteasomal function. J. Biol. Chem. 278 $11753-11759$.

Squier, T. C. (2001). Oxidative stress and protein aggregation during biological aging. Exp. Gerontol. 36, 1539-1550.

Stefanis, L., Larsen, K. E., Rideout, H. J., Sulzer, D., and Greene, L. A. (2001) Expression of A53T mutant but not wild-type alpha-synuclein in PC12 cells induces alterations of the ubiquitin-dependent degradation system, loss of dopamine release, and autophagic cell death. J. Neurosci. 21 , 9549-9560.

Striessnig, J., Koschak, A., SinneggerBrauns, M. J., Hetzenauer, A., Nguyen, N. K., Busquet, P., Pelster, G., and Singewald, N. (2006). Role of voltagegated L-type $\mathrm{Ca}^{2+}$ channel isoforms for brain function. Biochem. Soc. Trans. 34 903-909.

Sulzer, D., Bogulavsky, J., Larsen, K. E., Behr, G., Karatekin, E., Kleinman, M. H., Turro, N., Krantz, D., Edwards, R. H., Greene, L. A., and Zecca, L. (2000). Neuromelanin biosynthesis is driven by excess cytosolic catecholamines not accumulated by synaptic vesicles. Proc. Natl. Acad. Sci. U.S.A. 97, 11869-11874.

Sulzer, D., and Schmitz, Y. (2007) Parkinson's disease: return of an old prime suspect. Neuron 55, 8-10.

Surmeier, D. J. (2007). Calcium, ageing, and neuronal vulnerability in Parkinson's disease. Lancet Neurol. 6, 933-938.

Swartz, H. M., Sarna, T., and Zecca, L. (1992). Modulation by neuromelanin of the availability and reactivity of metal ions. Ann. Neurobiol. 32 Suppl. S69-S75.

Swerdlow, R. H., Parks, J. K., Miller, S. W. Tuttle, J. B., Trimmer, P. A., Sheehan, J. P., Bennett, J. P. Jr., Davis, R. E., and Parker, W. D. Jr. (1996). Origin and functional consequences of the complex I defect in Parkinson's disease. Ann. Neurol. 40, 663-671.

Taira, T., Saito, Y., Niki, T., Iguchi-Ariga, S. M., Takahashi, K., and Ariga, H.
(2004). DJ-1 has a role in antioxidative stress to prevent cell death. $E M B O$ Rep. 5, 213-218.

Takahashi, K., Taira, T., Niki, T., Seino, C., Iguchi-Ariga, S. M., and Ariga, H. (2001). DJ-1 positively regulates the androgen receptor by impairing the binding of PIASx alpha to the receptor. J. Biol. Chem. 276, 37556-37563.

Takahashi, N., Miner, L. L., Sora, I., Ujike, H., Revay, R. S., Kostic, V., JacksonLewis, V., Przedborski, S., and Uhl, G. R. (1997). VMAT2 knockout mice: heterozygotes display reduced amphetamine-conditioned reward, enhanced amphetamine locomotion, and enhanced MPTP toxicity. Proc. Natl. Acad. Sci. U.S.A. 94, 9938-9943.

Tanaka, Y., Engelender, S., Igarashi, S., Rao, R. K., Wanner, T., Tanzi, R. E., Sawa, A., V, L.D., Dawson, T.M., and Ross, C.A. (2001).Inducible expression of mutant alpha-synuclein decreases proteasome activity and increases sensitivity to mitochondria-dependent apoptosis. Hum. Mol. Genet. 10, 919-926.

Taylor, T. N., Caudle, W. M., Shepherd, K. R., Noorian, A., Jackson, C. R., Iuvone, P. M., Weinshenker, D., Greene, J. G., and Miller, G. W. (2009). Nonmotor symptoms of Parkinson's disease revealed in an animal model with reduced monoamine storage capacity. J. Neurosci. 29, 8103-8113.

Thannickal, T. C., Lai, Y. Y., and Siegel, J. M. (2007).Hypocretin (orexin) cell loss in Parkinson's disease. Brain 130, 1586-1595.

Turski, W. A., and Lachowicz, L. (1991). The possibility of participation of different protein kinases in the regulation of degradation of Glp6[125I] Tyr8SP6-11 with different endopeptidases in subcellular fractions of rat brain. Int. J. Biochem. 23, 317-321.

Uhl, G. R., Walther, D., Mash, D., Faucheux, B., and Javoy-Agid, F. (1994). Dopamine transporter messenger RNA in Parkinson's disease and control substantia nigra neurons. Ann. Neurol. 35, 494-498.

Valente, E. M., Salvi, S., Ialongo, T., Marongiu, R., Elia, A. E., Caputo, V., Romito, L., Albanese, A., Dallapiccola, B., and Bentivoglio, A. R. (2004). PINK1 mutations are associated with sporadic early-onset parkinsonism. Ann. Neurol. 56, 336-341.

Varastet, M., Riche, D., Maziere, M., and Hantraye, P. (1994). Chronic MPTP treatment reproduces in baboons the differential vulnerability of mesencephalic dopaminergic neurons observed in Parkinson's disease. Neuroscience 63, 47-56.

Victorof, J., Zarow, C., Mack, W. J., Hsu, E., and Chui, H. C. (1996). Physical 
aggression is associated with preservation of substantia nigra pars compacta in Alzheimer disease. Arch. Neurol. 53, 428-434.

Wickens, J.R., Reynolds, J. N., and Hyland, B. I. (2003). Neural mechanisms of reward-related motor learning. Curr. Opin. Neurobiol. 13, 685-690.

Wilms, H., Rosenstiel, P., Romero-Ramos, M., Arlt, A., Schafer, H., Seegert, D., Kahle, P. J., Odoy, S., Claasen, J. H., Holzknecht, C., Brandenburg, L. O., Deuschl, G., Schreiber, S., Kirik, D., and Lucius, R. (2009). Suppression of MAP kinases inhibits microglial activation and attenuates neuronal cell death induced by alpha-synuclein protofibrils. Int. J. Immunopathol. Pharmacol. 22, 897-909.

Wilms, H., Rosenstiel, P., Sievers, J., Deuschl, G., Zecca, L., and Lucius, R. (2003). Activation of microglia by human neuromelanin is NF-kappaB dependent and involves p38 mitogenactivated protein kinase: implications for Parkinson's disease. FASEB J. 17, 500-502.

Wood-Kaczmar, A., Gandhi, S., Yao, Z., Abramov, A. Y., Miljan, E. A., Keen, G., Stanyer, L., Hargreaves, I.,
Klupsch, K., Deas, E., Downward, J., Mansfield, L., Jat, P., Taylor, J., Heales, S., Duchen, M. R., Latchman, D., Tabrizi, S. J., and Wood, N. W. (2008). PINK1 is necessary for long term survival and mitochondrial function in human dopaminergic neurons. PLoS One 3, e2455. doi: 10.1371/journal. pone.0002455.

Xue, C. J., Ng, J. P., Li, Y., and Wolf, M. E. (1996). Acute and repeated systemic amphetamine administration: effects on extracellular glutamate, aspartate, and serine levels in rat ventral tegmental area and nucleus accumbens. J. Neurochem. 67, 352-363.

Yamada, T., McGeer, P. L., Baimbridge, K. G., and McGeer, E. G. (1990). Relative sparing in Parkinson's disease of substantia nigra dopamine neurons containing calbindin-D28K. Brain Res. 526, 303-307.

Zafar, S. K., Siegel, D., and Ross, D. (2006). A potential role for cyclized quinones derived from dopamine, DOPA, and 3 , 4-dihydroxyphenylacetic acid in proteasomal inhibition. Mol. Pharmacol. 70, 1079-1086.

Zarow, C., Lyness, S. A., Mortimer, J. A., and Chui, H. C. (2003). Neuronal loss is greater in the locus coeruleus than nucleus basalis and substantia nigra in Alzheimer and Parkinson diseases. Arch. Neurol. 60, 337-341.

Zeevalk, G. D., Bernard, L. P., and Nicklas, W. J. (1998). Role of oxidative stress and the glutathione system in loss of dopamine neurons due to impairment of energy metabolism. J. Neurochem. 70, 1421-1430.

Zecca, L., Zucca, F. A., Wilms, H., and Sulzer, D. (2003). Neuromelanin of the substantia niga: a neuronal black hole with protective and toxic characteristics. Trends Neurosci. 26 , 578-580.

Zhang, L., Shimoji, M., Thomas, B. Moore, D. J., Yu, S. W., Marupudi, N. I., Torp, R., Torgner, I. A., Ottersen, O. P., Dawson, T. M., and Dawson, V. L. (2005). Mitochondrial localization of the Parkinson's disease related protein DJ-1: implications for pathogenesis. Hum. Mol. Genet. 14, 2063-2073.

Zhang, Y., Gao, J., Chung, K. K., Huang, H., Dawson, V. L., and Dawson, T. M. (2000). Parkin functions as an E2-dependent ubiquitin-protein ligase and promotes the degradation of the synaptic vesicle-associated protein,
CDCrel-1.Proc. Natl. Acad. Sci. U.S.A 97, 13354-13359.

Conflict of Interest Statement: The authors declare that the research was conducted in the absence of any commercial or financial relationships that could be construed as a potential conflict of interest.

Received: 07 July 2010; accepted: 24 September 2010; published online: 20 October 2010.

Citation: González-Hernández T, CruzMuros I, Afonso-Oramas D, SalasHernández J and Castro-Hernández $J$ (2010) Vulnerability of mesostriatal dopaminergic neurons in Parkinson's disease. Front. Neuroanat. 4:140. doi: 10.3389/ fnana.2010.00140

Copyright (c) 2010 González-Hernández, Cruz-Muros, Afonso-Oramas, SalasHernández and Castro-Hernández. This is an open-access article subject to an exclusive license agreement between the authors and the Frontiers Research Foundation, which permits unrestricted use, distribution, and reproduction in any medium, provided the original authors and source are credited. 